\title{
Mechanisms of elimination of undesired evidence from criminal trial: a comparative approach
}

\author{
Mecanismos de exclusão de provas indesejáveis ao processo penal: \\ um estudo comparado
}

\section{Hanna Kuczyńska ${ }^{1}$}

Institute of Law Studies, Polish Academy of Science, Warsaw, Poland

hkuczynska@gmail.com

http://orcid.org/0000-0002-1446-2244

\begin{abstract}
AвSTRACT: This text presents two models of elimination of undesired evidence that operate in common law and continental law states. It analyses the mechanisms of blocking information from becoming evidence in a criminal trial which can be defined as the procedural instruments (solutions) adopted in a given model of criminal trial that allow for assessment and eventual elimination of inadmissible evidence as deemed to be undesired in the process of fact-finding. On the basis of a "model approach" it will be shown how such mechanisms of elimination (or blocking) of undesired evidence function in the United States and England, Germany, France, Poland and Italy. Also the stage of elimination will be analysed, as well as the type of procedure of applying a blockade. It will be explained in what ways the atomistic and holistic assessment of evidence work and what consequences they have. The last part of the text will show how the rationale for elimination of evidence in the form of illegality, unreliability or relevance, may result in various consequences depending on the seriousness of violation of law. These elements of analysis will allow to examine whether the continental and common law models of elimination of undesired evidence are coherent and effective and whether they allow for achieving the assumed goal of eliminating of undesired evidence. In the conclusions it will be shown that the final
\end{abstract}

1 Dr hab., professor at the Institute of Law Studies of the Polish Academy of Sciences in Warsaw, Criminal Law Department. 
arbiter of admissibility of evidence in both procedural models is a judge and how this solution allows for weighting legally protected interests in every case. The argumentation presented in the article will also lead to an observation that in the continental model of elimination of undesired evidence it cannot be said that there is a full-fledged "mechanism" of blocking information from becoming evidence in a criminal trial.

Kerwords: exclusionary rules; comparative criminal procedure; rules of evidence; admissibility of evidence.

Resumo: Este artigo pretende apresentar dois modelos de exclusão de provas indesejáveis que operam em ordenamentos continentais e de common law. São analisados os mecanismos de bloqueio de informações antes de se tornaram provas no processo penal, os quais podem ser definidos como instrumentos (soluções) adotadas em um determinado modelo de processo penal que permite a verificação e eventual exclusão de provas inadmissíveis pois definidas como indesejáveis à verificação dos fatos. Com base em uma "perspectiva de modelo", será descrito o funcionamento desses mecanismos de exclusão (ou bloqueio) de provas indesejáveis nos Estados Unidos e na Inglaterra, na Alemanha, na França, na Polônia e na Itália. Também serão analisados o estágio da eliminação e o tipo de procedimento para aplicar o bloqueio. Analisar-se-á o modo em que a análise atomística e holística da prova atua e as suas consequências. A última parte do texto irá demonstrar como a existência de distintos motivos para a exclusão da prova na forma de ilegalidade, não fiabilidade e irrelevância, a depender da gravidade da violação da lei, podem resultar em diferentes consequências. Isso permitirá verificar se os modelos continentais ou de common law são coerentes e efetivos e se eles atendem ao objetivo almejado de eliminar provas indesejáveis. Nas conclusões, será demonstrado que o árbitro final sobre admissibilidade da prova em ambos os modelos é o julgador e como isso autoriza a ponderação dos interesses legalmente protegidos em cada caso. Assim, também se observará que no modelo continental de exclusão de provas indesejáveis não se pode afirmar que há um mecanismo integralmente desenvolvido para bloquear informações de se tornarem provas no processo penal.

PalaVRas-Chave: regras de exclusão; processo penal comparado; teoria da prova; admissibilidade da prova. 


\section{INTRODUCTION}

In every system of criminal procedure there is evidence that is not desired in the process of fact-finding. In most legal orders, an undisputed obligation is that every court take into consideration certain legally protected values, even at the cost of not finding the truth or letting the perpetrator go free. Because of these protected values - becoming ever more endangered as states become technically capable of deeper intrusions into the sphere of individual privacy - in certain cases factfinding cannot be considered as an absolute value and must be subjected to certain limitations ${ }^{2}$. In every state, a mechanism of elimination of evidence must be also considered as a necessary systemic reaction to a violation of legal provisions by the state authorities in the process of evidence gathering. It is assumed that a system that remains indifferent to such violations could lead to total arbitrariness of state authorities in this

2 The need to take into account these other interests and guarantees of the rights of an individual makes the law of evidence a branch of a hybrid law - at the same time it contains the rules of the methodology of the criminal trial and is constitutes an expression of the moral principles and logic applicable in a given society: it has not only a normative but also an ethical dimension. See e.g.: NIJBOER, Johannes, F. Methods of Investigations and Exclusion of Evidence - a Comparative and Interdisciplinary Perspective. In: Beweisverbote in Ländern der EU und vergleichbaren Rechtsordnungen. HÖPFEL, Frank; HUBER, Barbara (eds.). Freiburg in Breisgau: Max-Planck-Institut, 1999, p. 49; ROBERTS, Paul; ZUCKERMAN, Adrian. Criminal Evidence. Oxford: Oxford University Press, 2012, p. 17; DAMAŠKA, Mirjam. Free Proof and Its Detractors. The American Journal of Comparative Law, n. 3(43), 1995, p. 348; HO, Hock Lai. Exclusion of Wrongfully Obtained Evidence: A Comparative Analysis. In: Oxford Handbook of Criminal Process. BROWN, Darryl et al. (eds.). Oxford: Oxford University Press, 2019, p. 833; WEIGEND, Thomas. The Potential to Secure a Fair Trial Through Evidence Exclusion: A German Perspective. In: Do Exclusionary Rules Ensure a Fair Trial?: A Comparative Perspective on Evidentiary Rules, GLESS, Sabine, RICHTER, Thomas (eds.). Basel: Springer, 2019, p. 62. On the role and importance of these values see: TURNER, Jenia I., WEIGEND, Thomas, The Purposes and Functions of Exclusionary Rules: A Comparative Overview. In: Do Exclusionary Rules Ensure a Fair Trial?: A Comparative Perspective on Evidentiary Rules, GLESS, Sabine, RICHTER, Thomas (eds.). Basel: Springer, 2019, p. 255-263, who also come to a conclusion that as to the rationales of the exclusion of evidence no clear divide exists between adversarial and inquisitorial systems, see p. 279. 
regard ${ }^{3}$. In consequence, a "blockade of information" must be introduced (in the German literature: Informationsblockade"4) - or a certain type of "evidentiary barrier", a "hurdle to admissibility" or a "filter". From a dogmatic point of view, such a blockade (barrier) can be perceived as a mechanism that operates in order to prevent "information" becoming "evidence". There are various types of such mechanisms across various states. They either operate in order to withhold information from the eyes of the fact-finder, or to not allow such information to become a basis for fact-finding. Consequently, mechanisms of blocking information from becoming evidence in a criminal trial can be defined as the procedural instruments (solutions) adopted in a given model of criminal trial that allow for assessment and eventual elimination of inadmissible evidence as deemed to be undesired in the process of fact-finding. This text will present the two models of mechanisms of elimination of undesired evidence that operate in common law states and continental law states and show that the exclusion of undesired information is administered differently in these two models of criminal trial.

3 See the literature in Poland: JASIŃSKI, Wojciech. Nielegalnie uzyskane dowody w procesie karnym. W poszukiwaniu optymalnego rozwiązania. Warszawa: Wolters Kluwer, 2019, p. 41 and in Germany: ROGALL, Klaus. Grundsatzfragen der Beweisverbote. In: Beweisverbote in Ländern der EU und vergleichbaren Rechtsordnungen. HÖPFEL, Frank, HUBER, Barbara (eds.). Freiburg in Breisgau: Max-Planck-Institut, 1999, p. 119, although the opinions on this topic in the common law states differ: see. e.g. PIZZI William. Trials Without Truth: Why Our System of Criminal Trials Has Become an Expensive Failure and What We Need to Do to Rebuild. New York: NYU Press, 1998 , p. 38 who writes "If the exclusionary rule is to protect citizens against police abuse it is a failure".

4 This terminology is used frequenlty in the German literature, among others by: ROGALL, Klaus. Grundsatzfragen der Beweisverbote, p. 125-126; KLEINKNECHT, Theodor. Die Beweisverbote im Strafprozess. Neue Juristische Wochenschrift, n. 19, 1966, p. 1539; KERN, Eduard; ROXIN, Claus. Strafverfahrensrecht: ein Studienbuch. München: Beck, 1987, p. 141; and in the French literature: BENEDICT, Jerome. Le sort des preuves illégales dans le procés pénal. Lausanne: Editions Pro Schola, 1994, p. 49.

5 See the notion used by DAMAŠKA, Mirjam. Evidentiary barriers to conviction and two models of criminal procedure: a comparative study. University of Pennsylvania Law Review, n. 121, 1973, p. 508.

6 ROBERTS, Paul, ZUCKERMAN, Adrian, Criminal Evidence... op.cit., p. 97. 
Across different states there are different barriers and different mechanisms of elimination of evidence - regarding rules of admissibility of evidence, the scope of evidence that should be eliminated, the functioning of such mechanisms, and the consequences of their application. The model of the mechanism of elimination mirrors the different methods of solving conflicts between the values that should be fulfilled by a criminal trial. Every model of admissibility of evidence must function in a different legal environment and in a different legal culture. In consequence, it has broader implications, "which somehow transcend the narrow bounds of the law of evidence and affect the working of the whole machinery of criminal justice, creating what can be perceived as 'the two evidentiary styles"' . Mechanisms adopted for elimination of evidence become one of the determinants of the given model of criminal trial: be it Anglo-Saxon or continental. In both legal traditions a certain "information blockade" exists - although in a different form - that allows for eliminating certain types of evidence from a fact-finder's (either a professional court or a jury) assessment - either before the trial, during the trial or in the process of fact-finding.

In this article a "model approach" will be presented: an attempt will be made to find and analyse the "model schemes" of mechanisms of elimination (or blocking) of undesired evidence in common law and continental law states. Comparative criminal law has adopted a method of conducting comparative research based on the created division into legal systems (models) belonging to the Anglo-Saxon common law tradition (in other words: the legal family ${ }^{8}$ ) that is a model of a strictly adversarial criminal procedure, and systems belonging to the tradition of continental law (civil law), known also as a mixed or non-adversarial model (by representatives of the first tradition also called the inquisitorial $\operatorname{model}^{9}$ ).

7 DAMAŠKA, Mirjam. Evidentiary barriers... op.cit., p. 508. PRADEL, Jean. La preuve en procédure pénale comparée. Rapport general, Revue International de Droit Penal 1992, p. 13.

8 In the normative sense: see GLENN, Patrick, H. Legal Traditions of the World. Oxford: Oxford University Press 2014, p. 366-367.

9 See: DAMAŠKA, Mirjam. On Structures of Authority and Comparative Criminal Procedure. Yale Law Journal, n. 84, 1974-1975, p. 481 FULLER, Lon, L. The Adversary System. In: Talks On American Law. BERMAN, Harold (ed.). 
The first group includes the models of English and United States trials, whereas Polish, French and German criminal procedures belong to the second group. The example of Italy cannot be ignored either, as it is presently the best example of a continental model of criminal procedure of increased adversariality. It introduced certain features of the common law model's approach to evidence (and thus became a kind of a "hybrid model"). This model approach has been used by comparativists on an international scale, in order to find, define, precise and analyze (also to label) contrasts between the above-mentioned models of administration of justice ${ }^{10}$. The concept of a "model" may be understood primarily as a "specimen" structure or procedure. Speaking of "legal traditions", authors often refer to "ideal models", or "theoretical models" of criminal trial $^{11}$ - as, for the purposes of comparative research, it is important to distinguish between a "normative model" of the criminal process in a given country, and an "ideal model" 12 - in other words a "theoretical model". In the theory of criminal trial, a model is understood as a "set of basic components of a system that allows differentiating it from other systems", a "common denominator"13. These components (simplifying) are constituted by specific procedural institutions, solutions used in a

New York: Vintage Books, 1971, p. 43-44; THIBAUT, John, WALKER, Lauren, LIND, E. Allan. Adversary presentation and bias in legal decisionmaking. Harvard Law Review. n. 86, 1972-1973, p. 390. In German literature: TRÜG, Gerson. Lösungskonvergenzen trotz Systemdivergenzen im deutschen und US-amerikanischen Strafverfahren. Tübingen: Mohr Siebeck, 2003, p. 26-27.

10 See: DAMAŠKA, Mirjam. The Faces of Justice and State Authority. New Haven-London: Yale University Press, 1986, p. 3. Also: LANGER, Maximo. From Legal Transplants to Legal Translations: The Globalization of Plea Bargaining and the Americanization Thesis in Criminal Procedure', Harvard International Law Journal. n. 1(45), 2004, p. 7-8.

11 Discussed in: WEBER, Max. On Law in Economy and Society. Harvard: Harvard University Press, 1954, and later by: LANGER, Maximo. From Legal..., op.cit., p. 7-8.

12 As in: ROBERTS, Paul. Faces of Justice Adrift? Damaška's Comparative Method and the Future of Common Law Evidence. In: Crime, Procedure and Evidence in A Comparative and International Context - Essays in Honour of Professor Mirjan Damaška. JACKSON, John, LANGER, Maximo (eds.). Oxford: Hart Publishing, 2008. LANGER, Maximo. From Legal..., op.cit., p. 7-8. 
criminal procedure, principles of criminal trial or functions performed by one of the actors in trial.

The model approach will allow for a generalised overview and - as with all model constructs - for finding common ground for discussions about comparative criminal procedure. Therefore, the research cannot go deeply into specific regulations functioning in the six analysed states. It must restrict itself to finding the general mechanisms governing the process of elimination of unwanted evidence. The first example of such an attempt to generalise the rules of the mechanism of elimination is the very title of this text, which speaks of "undesired evidence"; this concept is meant to signify all the potential evidence that, for many reasons, should not become evidence in a procedural meaning: both because of illegalities in the procedure of gathering and because of lack of credibility or lack of relevance of the evidence. When formulated in a more general way, as "undesired evidence" it provides a common platform to discuss the common features of grounds for exclusion of evidence in various legal orders.

Based on these assumptions in the text below, four aspects of different procedures aiming at elimination of such unwanted material will be analysed. These aspects function as components of every given model of elimination of evidence. They were selected on the basis of the fact that - despite many differences in the detailed form of the procedures in various states - these elements can be found to function in the same aim in every one of them. It is the aim - from the functional perspective which binds sometimes different procedures together and allows for a coherent analysis from a comparative point of view.

Firstly, different types of mechanisms of elimination will be presented: featured not on the basis of a name of an institution, or the reason of application, but on the basis of their aim and the function they play in a criminal trial. Four mechanisms may be differentiated: exclusionary rules, admissibility rules ${ }^{14}$, nullity of procedural actions, and general fairness of trial. These mechanisms may function separately or jointly in one model of criminal trial.

14 And these two mechanisms should not be mixed as it was mentioned by DAMAŠKA, Mirjam. Evidentiary barriers... op.cit., p. 515. 
Secondly, the stage of elimination will be analysed: whether the mechanisms of elimination function in the moment of acquiring and gathering information that may become evidence (blocking the information at the input stage), the stage of processing evidence (eliminating evidence while or after presentation at trial when the factfinder makes contact with them, at the output stage) or the stage of fact-finding (eliminating evidence from the process of fact-finding) ${ }^{15}$. At every stage of a criminal trial, certain mistakes, defects of evidence, may appear that lead to elimination of evidence.

Thirdly, the procedure of applying a blockade will be presented, during which a state authority may take a decision: it may be a pretrial hearing, a voir dire, or a motion to supress evidence procedure, a preliminary stage of trial before the evidentiary proceedings begins, as in Italy - which all allow for an atomistic assessment of evidence. Even a decision taken by a court during evidentiary proceedings by French, German or Polish judges constitutes a mechanism of atomistic elimination of evidence - as it plays the same role as the above mentioned mechanisms. This procedure may be also differently initiated: either on a motion of a party or ex officio. The procedure of elimination of evidence from the process of fact-finding may also happen in a holistic manner after the closure of evidentiary proceedings.

Fourthly, the consequences of application of a mechanism of elimination of evidence may differ: usually in most legal orders the reason for elimination may be illegality, unreliability and relevance of evidence. The meaning every legal system gives to these grounds of elimination is different. Also the consequences differ not only depending on the type of deficiency of evidence but also depending on the seriousness of violation of law - and here the mechanism of "balancing of legal interests" will be described.

15 The same structure of analysis of illegaly obtained evidence is marked in: HO, Hock Lai. Exclusion of Wrongfully... op.cit., p. 822 and: AMELUNG, Knut. Zasady rządzące zakazami wykorzystania dowodów. In: Współczesne problemy procesu karnego i wymiaru sprawiedliwości. Księga ku czci Profesora Kazimierza Marszała. HOFMAŃSKI, Piotr; ZGRYZEK, Kazimierz (eds.). Katowice: Wydawnictwo Uniwersytetu Śląskiego, 2003, p. 17. 
The purpose of advancing these models will be to analyze how the above-mentioned elements of the researched models of elimination of evidence operate. They must be evaluated in the light of the question of whether each model is coherent and effective, and whether it allows for achieving the stated goal of elimination of undesired evidence. The analysis will make it possible to find out whether this mechanism of blocking information from becoming evidence in a criminal trial functions properly, and to identify any deficiencies in the models researched. The research will also go into evaluation of the consequences of elimination of evidence that will show why the result of determining the inadmissibility of a piece of evidence should be practical elimination of such documents from the case file. It is also important to compare the connections of the adopted model of elimination of evidence with the principles of criminal trial. The most important conclusion is that a criminal trial can be considered to be adversarial only if the rules of admissibility of evidence operate on equal terms for both parties, and when issues of admissibility are adjudicated in a clear and equal procedure.

\section{MeChanisms of ELIMINATION OF UNDESIRED EVIDENCE}

In order to eliminate undesired evidence from criminal trial four different mechanisms can be used: rules of exclusion (which forbid gathering certain evidence or in a certain way); admissibility rules (which dictate what types of evidence can be admitted at trial), nullity of procedural actions (which treats evidence as if it did not exist, as the consequence of violations of the rules in procedural actions taken by the state authorities), and finally the evaluation of the general fairness of a trial by a judge, performed through free assessment. In most legal systems these mechanisms function jointly - although sometimes at different stages of trial. However, their meaning and the method of their application differ between the common law states and continental states. In the Anglo-Saxon model, a clear scheme exists that allows for elimination of inadmissible evidence at successive stages of assessment, and is based on statutory rules. In the continental model a judge acts according to the "free proof" theory and is free to decide on the evidence that will be admissible - as there are no strict rules of admissibility. In 
consequence it can be observed that in the latter model the decision as to the admissibility of evidence is "shifted" to the stage of decision of a judge.

\section{The Anglo-Saxon Approach}

In the Anglo-Saxon states, the scheme of admissibility rules is based on four foundations: the list of admissible evidence, rules of exclusion and rules of admissibility, and the final stage of assessment of general fairness of the proceedings. "The law of admissibility" is defined as the law that regulates whether a particular piece of evidence should be received - or "admitted" - into the trial ${ }^{16}$. The aim of these rules and the function they fulfil is to determine whether to allow the fact-finder to be informed about a piece of evidence and to give them the opportunity of taking it into account in arriving at their verdict. Deciding on admissibility of evidence, the judge "regulates the informational resources available to the fact-finder" 17 .

In this model of evidentiary law, the assessment of admissibility of evidence takes place at several stages (which can be described as "hurdles to admissibility", corresponding to a series of questions that a trial judge must ask while assessing evidence ${ }^{18}$ ): first in a positive and later in a negative aspect and then again in positive. The positive aspect means that evidence is only admissible in a certain form according to the rules provided by a legal act. This assessment must also relate to the question of whether the evidence is relevant - irrelevant evidence is conclusively inadmissible and does not have to undergo the next stages of assessment. After this assessment, the character of the evidence may result in an observation that evidence falls within rules of exclusion (such as client privilege or state secrets), which means an assessment in a negative aspect. In the case of rules of exclusion, the exclusion should be automatic ${ }^{19}$. As to other

16 ROBERTS, Paul, ZUCKERMAN, Adrian. Criminal Evidence .... op.cit., p. 96.

17 ROBERTS, Paul, ZUCKERMAN, Adrian. Criminal Evidence ... op.cit., p. 97.

18 ROBERTS, Paul, ZUCKERMAN, Adrian. Criminal Evidence... op.cit., p. 97; DAMAŠKA, Mirjam. Evidentiary barriers ... op.cit., p. 508.

19 CHOO, Andrew. England and Wales: Fair Trial Analysis and the Presumed Admissibility of Physical Evidence. In: Exclusionary Rules in Comparative 
evidence, not falling into one of the above categories, it is presumptively admissible, but may be excluded through the exercise of judicial discretion to exclude prosecution evidence in order to ensure a "fair trial". At this stage, an assessment of admissibility may take place also in the form of applying "soft" standards.

The best example of this mechanism of assessment of evidence functions in the English legal order, where on the basis of s. 78 PACE 1984, if it appears to the court that, having regard to all the circumstances, including the circumstances in which the evidence was obtained, the admission of the evidence (on which the prosecution proposes to rely) would have such an adverse effect on the fairness of the proceedings, the court ought not to admit it. At the final stage the inclusionary exceptions should be analysed (again, an assessment in a positive aspect) - those that can be used for admitting hearsay (in the English legal order that is s. 114-118 CJA). Inclusionary rules can rescue evidence from presumptive inadmissibility. As a consequence of numerous exceptions, evidence rendered presumptively inadmissible by the application of an exclusionary rule at the last stage of assessment can turn out to be admissible thanks to the "protective wing of an inclusionary rule" ${ }^{20}$. The final arbiter of admissibility is a judge, using free evaluation - however, based on jurisprudence ${ }^{21}$. This discretion is limited by the legal provisions of the CJA - s. 126 states that "in criminal proceedings the court may refuse to admit a statement as evidence of a matter stated if (a) the statement was made otherwise than in oral evidence in the proceedings, and (b) the court is satisfied that the case for excluding the statement, taking account of the danger that to admit it would result in undue waste of time,

Law. THAMAN, Stephen (ed.). Dordrecht - Heidelberg - New York - London: Springer, 2013, p. 331, who counts that there are, in essence, three automatic exclusionary rules: evidence obtained by torture; the admission in evidence of communications intercepted illegally; a confession made by an accused person that was obtained by oppression, or by words or actions conducive to unreliability. ROBERTS, Paul, ZUCKERMAN, Adrian. Criminal Evidence ... op.cit., p. 98. See e.g.: R v. Jeffries and Chalkley (1998) 2 Cr App R 79; y R v. Latif (Khalid), [1996] WLR 104; Attorney-General Reference (No. 3 of 2000) 1 WLR 2060, R v. Loosely, [2001] UKHL 53; R v. Smurthwaite (1994) 98 Cr App R 437; R v. List (David), [1966] 1 WLR 9; 
substantially outweighs the case for admitting it, taking account of the value of the evidence". This section can be seen both as a rule limiting the inclusionary discretion and as an exclusionary rule. Only after the three-tier evaluation does information become evidence. In the United States a similar formula applies on the federal level as it results from rules 403-415 of the Federal Rules of Evidence ${ }^{22}$.

\section{The Continental Approach}

The continental model of admissibility of evidence is much simpler: there is no positive list of evidence: the free proof rule reigns ${ }^{23}$. However, the mechanism of elimination of evidence also takes a mixed form: both rules of exclusion and admissibility rules. Rules of exclusion are prohibitions of all types that limit the power to gather or use evidence ${ }^{24}$. In this case the source of these rules is a legal act - the legal act also decides about the ban on gathering/using such evidence. However, this is not the case for all of the rules of exclusion - the legal consequences of only specific parts of rules of exclusion are decided by the legal act. As to the remaining part, the rules of judicial freedom of decision apply characteristic of the second stage of assessment.

The second stage of assessment regards evaluation of the evidence in the light of the rules of admissibility. Generally in continental states these rules are not clearly described. The consequences of deficiencies of evidence are not provided for by a legal act. The final decision is left to the free assessment of a judge. The judge can act on the basis of a conviction that a certain piece of evidence is "inadmissible". This decision finds its grounds in the continental codes of criminal procedure (in Poland it is art. $170 \S 1$ of the code of criminal procedure - k.p.k., and

22 As amended December 1, 2020, see: https://www.law.cornell.edu/rules/fre (access 7.12.2020).

23 DAMAŠKA, Mirjam. Free Proof ... op.cit., p. 347-348.

24 SKORUPKA Jerzy. Eliminowanie z procesu karnego dowodów uzyskanych w sposób sprzeczny z prawem. In: Dowody. Vol. VIII(2), System Prawa Karnego Procesowego. SKORUPKA, Jerzy (ed.). Warszawa: Wolter Kluwer 2019, p. 2767. 
in Germany \& 244(1) StPO). These provisions both stipulate that it is possible to overrule an evidentiary motion of a party when such evidence is "inadmissible" (niedopuszczalny, unzulässig) - and the interpterion of this notion is left to a casuistic decision of a judge. Also rules of general character that forbid using certain types of information constitute an equal source of inadmissibility: rules of criminal procedure (such as the fair trial principle), the Constitution or the ECHR.

In consequence, there is no possibility to formulate certain and clear rules of admissibility that would be known in advance. Thus, the decision as to the admissibility of evidence is "shifted" to the stage of decision of a judge. It is the judge who decides on the basis of assessment of the potential value for fact-finding and the harm done to the rights of the accused as well as principles of a fair trial ${ }^{25}$. It may be noticed that in this way the courts - above all the Supreme Courts - go beyond the "normal" continental role - "interpretative" and "commentatory" - and enter into the domain of law-making, providing for a model reaction on undesired evidence. The continental judge not only decides about the admission of all the evidence (both applied for by the parties and ex officio) but later decides about the value of this evidence during the fact-finding stage.

After these two stages of assessment of the evidence, the final stage is the holistic evaluation of the totality of evidence presented (or revealed) in the case as to credibility, relevance and meaning for the case. It is characteristic of the continental model that these three stages of evaluation of evidence can take place both during atomistic, a priori evaluation, and during the holistic stage of evaluation. At the latter stage, this model rejects formal rules of evaluation of evidence: both as to the credibility of evidence and to its relevance. On the continent it is believed that it is not possible to decide a priori, on the level of a legal act, about the relevance and credibility of evidence ${ }^{26}$. As a professional, the factfinder does not have to be protected by numerous rules of admissibility

25 On this rationale as a ground for exclusion see: HO, Hock Lai. The Fair Trial Rationale for ExcludingWrongfully Obtained Evidence. In: Do Exclusionary Rules Ensure a Fair Trial?: A Comparative Perspective on Evidentiary Rules, GLESS, Sabine; RICHTER, Thomas (eds.). Basel: Springer 2019, p. 288.

26 DAMAŠKA, Mirjam. Evidence Law Adrift, Yale: Yale University Press, 1997, p. 20, DAMAŠKA, Mirjam. Evidentiary barriers ... op.cit., p. 515. 
of evidence as they can professionally assess the relevance and credibility and the weight of the evidence. From the continental point of view the alternative would signify shifting the "decision-making centre" to the level of a legal act from the level of the free assessment of a judge ${ }^{27}$.

The theory of free proof in this model is bound to the overwhelming importance of free evaluation of evidence - the emphasis in the procedure of evaluation is placed on the "ordinary process of cognition" of judges, who are supposed to arrive at "an intime conviction" about guilt ${ }^{28}$. In the Anglo-Saxon model evidence is declared by the legal provision to be unreliable because of the way it was obtained, and is considered to be inadmissible at the first positive stage of assessment of admissibility. Thus, the stage of credibility assessment differs between the two models: in the Anglo-Saxon model it is an a priori assessment, in the continental model - a posteriori assessment ${ }^{29}$. In the continental model, evidence that lacks credibility will most often be presented and subjected to a holistic analysis, although this is not a rule: it may also be rejected a prori on the basis of statutory premises as "inadmissible".

When analysing the system of elimination of undesired evidence in continental states one cannot forget about the mechanism of "nullity" of a procedural legal action or "evidentiary nullity". This mechanism

27 STEINBORN, Sławomir. Aksjologiczne uwarunkowania ograniczeń w dochodzeniu do prawdy materialnej w procesie karnym. In: Pojęcie, miejsce i znaczenie prawdy materialnej $\mathrm{w}$ polskim procesie karnym: materiały Wrocławskiego Seminarium karnoprocesowego. SKORUPKA, Jerzy; KREMENS, Karolina (eds.). Wrocław 2013, p. 98-107.

DAMAŠKA, Mirjam. Free Proof and Its Detractors ... op.cit., p. 348.

WEIGEND, Thomas. Germany. In: Toward a Prosecution for the European Union. Vol I. LIGETI, Katalin (ed.), Oxford: Hart Publishing, 2013, p. 296297; BILLIS, Emmanouil. Die Rolle des Richters im adversatorischen und im inquisitorischen Beweisverfahren. Berlin: Duncker \& Humblot, 2015, p. 64; ROGALL, Klaus. Beweisverbote im System des deutschen und des amerikanischen Strafverfahrens-rechts. In: Zur Theorie und Systematik des Strafprozessrechts: Symposium zu Ehren von Hans-Joachim Rudolphi. WOLTER, Jürgen (ed.). Berlin: Luchterhand, 1995, p. 113-160; GRÜNWALD, Gerald. Das Beweisrecht der Strafprozeßordnung, Baden-Baden: Nomos,, p. 143; GLESS, Sabine. Das Verhältnis von Beweiserhebungs-und Beweisverwertungsverboten und das Prinzip »Iocus regit actum. In: Festschrift für Gerald Grünwald, SAMSON, Erich, DENCKER, Friedrich, FRISCH, Peter, FRISTER, Helmut, REIß, Wolfram (eds.). Baden-Baden: Nomos, 1999, p. 197-198. 
functions in France and Italy. There is a special procedure that allows for nullification of actions taken by state authorities, and all the consequences of such. As a result of such a decision, evidence must be considered nonexistent - ex tunc (by textual nullities) or may be pronounced null and void, where a violation of formalities has had the effect of damaging the interests of the party concerned (by substantive nullities) ${ }^{30}$. A nullity is a defect in the act, hypothetically, where a legitimate power to gather evidence was exercised in a way that did not conform to the law - and thus should be distinguished from "non-usability of evidence", which refers to prohibited evidence ${ }^{31}$. It is also a mechanism of elimination of evidence as well - but not in the result of evaluation of substantive value and meaning of evidence but only formal premises of executing a legal action by state authorities.

From the point of view of the Anglo-Saxon literature, this model of management of evidence is chaotic and unpredictable. However, from the continental point of view, this perspective is mistaken. Anglo-Saxon lawyers focus on courtroom rules and consider the rules of admissibility only from this perspective. Therefore, they often omit the numerous evidentiary rules that apply at the stage of investigation. This is the main forum for application of detailed evidentiary law in the continental model of criminal procedure - as writes J. Ross ${ }^{32}$. Evidentiary rules tend to be activated mostly at the stage of gathering evidence (before acquiring evidence), not just at the stage of presentation. The lack of admissibility

30 PRADEL, Jean. Procedural Nullities and Exclusion,. In: Exclusionary Rules in Comparative Law. THAMAN, Stephen (ed.). Dordrecht - Heidelberg - New York - London: Springer, 2013, p. 148. In the Anglo-Saxon literature this method of reaction is considered to be „older” than „modern” exclusionary rules. See: THAMAN, Stephen. Balancing Truth Against Human Rights: A Theory of Modern Exclusionary Rules. In: Exclusionary Rules in Comparative Law. THAMAN Stephen (ed.). Dordrecht - Heidelberg - New York London: Springer, 2013, p. 410, who explains how "nullities", in the abstract, differ from modern exclusionary rules.

31 ILLUMINATI, Giulio. Italy: Statutory Nullities and Non-usability., In: Exclusionary Rules in Comparative Law. THAMAN, Stephen (ed.). Dordrecht Heidelberg New York London: Springer, 2013, p. 244-245.

32 ROSS, Jacqueline. Do Rules of Evidence Apply (Only) in the Courtroom? Deceptive Interrogation in the United States and Germany. Oxford Journal of Legal Studies, n. 3(28), 2008), p. 444. 
rules applicable at trial does not mean that there are no rules determining the desired shape of information in order to become evidence. It only means that there are two possible ways of acquiring the desired form of evidence: either at the stage of gathering or at the stage of presentation. In the first model, only information gathered and preserved in a specific form may be presented during trial. Investigative rules function as evidentiary rules to the extent that they filter and shape the information that reaches the trier of fact. Exactly like Anglo-Saxon rules of evidence, continental investigative rules transmute raw data into evidence, determining which information reaches the fact-finder, and the manner in which it is framed. In consequence, as J. Ross argues: this difference leads to a conclusion that the rules (specifically interrogation rules) that operate at such an early stage of procedure, are better seen as norms designed to protect the accused from the police - whereas the Anglo-Saxon rules have a primary goal of keeping certain facts from the fact-finder. "This makes evidentiary rules difficult to evade" 33 . Nonetheless, it has to be stressed that this rule only applies to the evidence gathered by the accusation in the preparatory proceedings - and does not operate at trial, when parties present their evidentiary motions that are to be assessed by the judge during trial.

\section{The STAGE OF ELIMINATION OF UNDESIRED EVIDENCE}

It is important to determine at what stage the decision as to the elimination of evidence is taken. One can speak of "blocking information" from becoming "evidence" when two stages are considered: gathering of evidence and presentation in trial (then information does not become evidence). However, once evidence is included in the preparatory proceedings file (in the continental model) or presented at trial (in both models) it is not the notion of "blocking of information" that should be used but "disqualification". In the last case, the fact-finder has knowledge of the evidence, but cannot use it in the fact-finding process. Elimination of evidence can thus take both the form of blocking of information and

33 ROSS, Jacqueline. Do Rules ... op.cit., p. 472. 
its disqualification. In the doctrine of comparative criminal procedure it has been established that that the Anglo-Saxon courts base their decisions mainly on the "atomistic", prior, evaluation of evidence, whereas the continental judges evaluate evidence in a holistic, total, manner, after termination of evidentiary proceedings. However, it will be shown below, that this conviction is not entirely precise.

\section{The Anglo-Saxon Approach}

In the Anglo-Saxon model, the scheme of elimination of evidence is clear: there is no possibility to consider the notion of "evidence" before the trial stage, as there is no formal investigation stage. Therefore, this model more often and usually results in "blocking of information". It is only after issuing an indictment that the problem of "forging" information ("data", "information about evidence") into "evidence" appears in the procedural meaning ${ }^{34}$. Such types of blocking of evidence rely on a priori evaluation of admissibility of evidence. It has been established in the doctrine of comparative criminal procedure that the Anglo-Saxon courts are based mainly on the "atomistic" evaluation of evidence ${ }^{35}$. Atomistic assessment signifies evaluation of every piece of evidence separately: according to rules of exclusion, admissibility rules, credibility, relevance and legality. In consequence, only admissible evidence can be presented at trial, and no information can reach the eyes of the fact-finder if it has not become evidence in the procedural sense ${ }^{36}$. In this model, the inadmissible evidence remains "frozen" before trial and does not reach the eyes of the fact-finder. This type of blockade eliminates the danger of "contamination" of the fact-finder's mind with information that should not be included in the evidentiary material. In this model the atomistic evaluation of evidence comes into play on two stages of criminal proceedings: before trial during

34 VAN CAENEGEM, William. New trends in illegal evidence in criminal procedure: general report - common law, Paper presented at XIII World Congress of Procedural law, Rio de Janeiro, Brazil. https://research.bond.edu.au/en/ publications/new-trends-in-illegal-evidence-in-criminal-procedure-general-repo (access: 18.11.2020).

DAMAŠKA, Mirjam. Evidentiary barriers ... op.cit., p. 519-520.

DAMAŠKA, Mirjam. Evidentiary barriers ... op.cit., p. 519-520. 
various types of pre-trial hearings and during trial in the form of a ruling over an objection of the opposite party. In the latter procedure it may relate to an entire piece of evidence (a certain witness) or a part of this evidence (a certain question to a witness, e.g. during cross-examination).

However, it is not possible to claim that in the Anglo-Saxon model of criminal procedure, only an atomistic assessment of evidence is conducted. The fact-finder after presentation of all evidence must proceed with its holistic evaluation. It is not an assessment of the admissibility of evidence, but of value and relevance for the case, as well as credibility. It must also take into consideration the summary by the presiding judge, where s/he informs the jury about the potential problems with the credibility of evidence (as in the case of doubtful confessions). Nonetheless, the holistic assessment is not part of the mechanism of elimination of evidence, but of its evaluation.

\section{The Continental Approach}

At the same time, the continental states are considered to exercise only holistic assessment of evidence (a posteriori) ${ }^{37}$. According to this concept the totality of evidence undergoes a total assessment after finalization of evidentiary proceedings ${ }^{38}$. This method of assessment of admissibility of evidence has the result that the blockade of information works only at the stage of fact-finding. It is more "disqualification" of evidence than "blocking", as it takes place in the process of fact-finding. Although when the fact-finder disposes of certain information they decide to "forget about" their influence on the findings - it is "the law's demand that evidence be disregarded" ${ }^{39}$. However, this simplified position

37 DAMAŠKA, Mirjam. Free Proof ... op.cit.., p. 349 and in the Polish literature: JASIŃSKI, Wojciech. Nielegalnie ... op.cit., p. 74.

38 DAMAŠKA, Mirjam. Free Proof ... op.cit., p. 349; TWINNING, William. Theories of Evidence: Bentham and Wigmore. (Jurists: Profiles in Legal Theory). London: Stanford University Press 1985, p. 183-185.

39 DAMAŠKA, Mirjam. Free Proof ... op.cit., p. 350, who argues that on this stage of fact-finding "the implementation of exclusionary rules is psychologically difficult and easily acquire an aura of unreality". 
cannot be supported, as it does not refer to two relevant aspects of the continental evidentiary law.

Firstly, inadmissibility of evidence can stem not only from the way of gathering of this evidence, which can be perceived before trial, but also from the way of using it in trial (e.g. if a witness refused to testify, thus his/her earlier testimony cannot be considered to constitute evidence). In this situation it is sometimes impossible to predict that certain evidence may become illegal as a result of their use in trial. Evidence that is legal in preparatory proceedings can become illegal at trial - as the "defectiveness" may arise at trial.

This situation is explained in the German literature: a rule of exclusion (Beweisverbote) is either a rule excluding gathering evidence (Beweiserhebungsverbote) or a rule excluding the use of evidence (Beweisverwertungsverbote $)^{40}$. Both types of rules play the same role: they "block" the use of information by the judge ("Informationsblockade") in the process of fact-finding ( $\$ 261 \mathrm{StPO}$ ). However, there is no automatic, legally established, reaction to either type of "defectiveness". The StPO does not provide for an information, what the consequences of using such evidence are ${ }^{41}$. These two types of rules of admissibility are not necessarily bound to each other. A rule excluding the use of evidence does not always stem from, nor is it always a derivative of a rule excluding gathering evidence. Usually it is so but there are many situations where a rule excluding the use of evidence is of an independent character ${ }^{42}$. Additionally, besides these two types of rules of admissibility, there may be also rules forbidding the use of evidence on a third stage: the rule excluding the possibility to conduct fact-finding on the basis of certain evidence - in the case of the continental model it would be often a "soft" prohibition, e.g. as in the case of rule forbidding fact-finding on the basis of incredible evidence ${ }^{43}$.

40 KLEINKNECHT, Theodor. Die Beweisverbote im Strafprozess. Neue Juristische Wochenschrift, n. 19, 1966, p. 1539; KERN, Eduard; ROXIN, Claus. Strafverfahrensrecht: ein Studienbuch. München: Beck, 1987, p. 141.

41 BENEDICT Jerome. Le sort des preuves ...op.cit., p. 51.

42 ROGALL, Klaus. Grundsatzfragen der Beweisverbote.... op.cit., p. 126.

43 KWIATKOWSKI, Zbigniew. Model zakazów dowodowych de lege lata w polskim procesie karnym. In: Nowe spojrzenie na model zakazów dowodowych 
In the French doctrine the notion of "legal evidence" (preuves legales) is distinguished from "legality of evidence" (legalité des preuves). Whereas the first notion relates to evidence which is not in conformity with the rules established in the legal act, the second relates to the way of administering of the evidence (l'interdictions d'utilisation) ${ }^{44}$. In the second case, legality should be connected with the way of presentation the evidence in a courtroom (l'administration de preuves). In the hybrid model of criminal trial (continental with increased adversariality) in Italy "non-usability" can be understood as a prohibition on admitting evidence (a priori) or a prohibition on taking it into account in the process of factfinding (a posteriori). As it is admitted: "Inadmissibility of evidence and a prohibition on evaluating it are two sides of the same coin, in the sense that if evidence cannot be admitted, neither may it be evaluated and, vice versa, if it may not be used for the decision, it should not be admitted" ${ }^{45}$.

Secondly, the atomistic evaluation of evidence takes place at trial when the presiding judge makes a decision on every single piece of evidence before its presentation, ruling on its admissibility according to the codified premises, though very general ones. In consequence, there is a barrier between "evidence" in preparatory proceeding and in trial. Even if evidence is included in the case file, the decision of a judge is needed in order to include it into the caseload. A court is not bound by the assessment conducted by an investigative organ: even if certain information was considered to be evidence in preparatory proceedings, the court is not exempted from its independent assessment ${ }^{46}$. It is only the decision of the judge that allows for its "metamorphosis". However, although this scheme seems to be clear, it is characteristic that the notion

w procesie karnym. SKORUPKA, Jerzy (ed.). Warszawa 2014, p. 61.

BENEDICT, Jerome. Le sort des preuves ... op.cit., p. 20; GIUDICELLI-DELAGE, Geneviève. Les transformations de l'administration de la preuve pénale. Perspectives comparées : Allemagne, Belgique, Canada, Espagne, Etats-Unis, France, Italie, Portugal, Royaume-Uni. Archives de politique criminelle, n. 26(1), 2004, p. 72.

ILLUMINATI, Guilio. Italy: Statutory Nullities, p. 240.

WILIŃSKI, Paweł. Konstytucyjny standard legalności dowodu w procesie karnym In: Proces karny $\mathrm{w}$ dobie przemian. Zagadnienia ogólne. STEINBORN, Sławomir., WOŹNIEWSKI, Krzysztof (eds.). Gdańsk: Wydawnictwo UG, 2018, p. 310 . 
of "evidence" is often used in an "atechnical" manner in the continental literature: signifying not only evidence allowed by the judge in trial but also a source of information, the result of presenting evidence - and is also applicable during the investigative phase ${ }^{47}$.

Atomistic assessment of evidence is conducted on the basis of premises that allow the court to reject the evidentiary motion (art. $170 \S 1$ k.p.k. or $\S 244$ ust. 3 StPO). In the continental states for the evidentiary law of key importance is the notion of an "evidentiary motion" (Beweisantrag), by which is meant a demand on behalf of a party to the proceedings, directed to the court to allow for presentation of the evidence (see: art. 167 k.p.k., § 219(1) StPO, art. 444 French c.p.p.). In this model of evidentiary proceedings it is the court that admits evidence. The role of a party in the perspective of presentation of evidence is a role of a "petitioner", an "informant" who draws the attention of the court to the possible evidence that could be relevant in the case. This power is accompanied by a "twin power" to admit evidence ex officio, giving to the judge the power of evidentiary initiative. It is the decision of the court that transforms "information" into "evidence" for the purpose of a trial. This power makes it a dominant organ that controls the totality of evidentiary proceedings. The last element of this model is lack of procedure in which it would be possible to control the court's power as there is no appeal procedure for this decision. A decision not to admit evidence can be usually appealed only during an appeal procedure. Also a French judge must assess evidentiary motions before trial or during trial (art. 444 c.p.p., art. $6 \mathrm{ECHR}^{48}$ ), based on either on prohibitions on the use of evidence scattered throughout the code of criminal procedure (e.g. art. 432 c.p.p. prohibiting the use as evidence correspondence between a lawyer and his/her client, or art. 706-62 c.p.p., prohibiting ruling basing solely on the anonymous witness' testimonies), or on the basis of rules interpreted from the general procedural principles, which are considered: legalism, loyalty, proportionality and dignity ${ }^{49}$. In this model of elimination of evidence, the decision is taken by the same authority

\footnotetext{
47 ILLUMINATI, Giulio. Italy: Statutory Nullities ... op.cit., p. 239.

48 PRADEL, Jean. Procédure pénale, Paris: Cujas, 2014, p. 774.

49 PRADEL, Jean. Procédure pénale ... op.cit., p. 354-357.
} 
which decides on the facts of the case (even in the case of a jury trial in Italy and France, as the jury is then unified with the professional court) and the fact-finder is (at least partly) a professional.

In consequence, the continental model uses a double mechanism of elimination of evidence: before admitting evidence to be presented in the trial, the presiding judge a priori assesses the evidence is "admissible" and during the fact-finding process, when the judge decides about the facts of the case. There are no "positive" rules that would describe what premises should be fulfilled in order to admit a certain piece of evidence. The judge can apply all the elements of assessment: legality, relevance to the case, actual feasibility of conducting - and also the rules of a fair trial. Whereas the Anglo-Saxon model introduces positive premises ("evidence should be relevant and credible"), the continental law disposes of "negative" premises ("evidentiary motion will be rejected if it is irrelevant or inadmissible"). Both constructs assume that the potential sources of information are assessed a priori, in an atomistic model.

On the other hand, if some evidence has already been introduced at the continental trial, it is re-assessed in a holistic manner after the trial (by the same person or persons), i.e. in the perspective of its importance in the light of all the evidence presented in the case. This is also the stage where the credibility of the evidence is most often assessed and, again, its significance for the case, if the initial control did not lead the court to the conclusion that the evidence should be inadmissible. After the evidence has been introduced in trial, judges have to decide whether they can base their decision on the evidence or they will try to "forget" about it and not base a decision on it. If the evidence has already been used or conducted, then at the a posteriori evaluation stage there can be no question of a blockade on use. At most it can be a disqualification of such evidence in the process of fact-finding. In the latter situation, the judge has to "erase" his/her knowledge gained from excluded evidence - obtained by reading in case files exhibits or by observing the presentation of conducted evidence in trial. This leads to a dilemma as to whether s/he will be able to do it effectively. If not, the elimination of the evidence is only formal, not real ${ }^{50}$.

50 GLESS, Sabine. Germany: Balancing Truth Against Protected Constitutional Interests. In: Exclusionary Rules in Comparative Law. THAMAN, Stephen 
From the normative point of view this model is clear. However, the practical application of these solutions raises many questions - especially in regards to the evidence presented by the prosecutor in the case file. The decision about including certain pieces of evidence into evidentiary material is taken after a judge gets acquainted with them reading the case file. In consequence, a continental judge enters a courtroom equipped in the knowledge of all the evidence gathered so far in the case at the stage of investigation (in the continental states known as preparatory proceedings $)^{51}$. Thus, the method of dealing with evidence is necessarily connected with the existence of a dossier of a criminal case. The judge decides about admissibility of evidence while often having prior knowledge of its content. Moreover, if the evidence is included in the case file, the judge can order that that documents in case file are considered to be "disclosed" at trial. This decision, expressed in the minutes of the trial includes the "disclosed" evidence in the frames of evidentiary material. Such a legal construct is absent in Anglo-Saxon trials.

\section{Procedure of assessment of admissibility of eVidence}

In every legal order a mechanism of elimination of evidence should take the form of a certain procedure that will construct a procedural forum of assessment of admissibility. In the Anglo-Saxon states the admissibility of evidence is decided during a special type of an adversarial procedure, by a professional judge in the absence of the jury. This model allows for both a thorough analysis of admissibility of evidence and for keeping such doubtful evidence from the eyes of the adjudicator. Contrary to this, in the continental states there is no special procedure and forum for such an assessment, as the admissibility of evidence is evaluated by a professional judge usually at trial or at best during a in camera hearing.

(ed.). Dordrecht - Heidelberg - New York - London: Springer 2013, p. 118, who observes that „This dilemma brings about a strong risk of diluting the impact of exclusionary rules".

51 This is usually not true in the Italian criminal proceedings as it does not belong to a strictly continental model of criminal procedure but to its more adversarial version, that could be called "the continental model of increased adversariality". 


\section{The Anglo-Saxon Approach}

The mechanism of blocking information in the Anglo-Saxon model of evidentiary law functions at many stages. The first stage takes place before trial: after disclosure (discovery) of evidence of the opposite party the parties issue motions to declare certain pieces of evidence as inadmissible (in the United States it is a "motion to supress"). In such a motion the party must specify with particularity the grounds upon which the motion is based (e.g. by alleging that the evidence in question was obtained from the defendant incident to an arrest that was not made upon probable cause or lack of "voluntariness" of a confession) ${ }^{52}$. The motions are usually recognised during a pre-trial hearing: depending on a legal system such hearings have different names and are either dedicated solely to admissibility issues or also other issues can be decided. E.g. in the United States there is a special type of procedure known as a suppression hearing. In England in the magistrates' courts there are pre-trial hearings and in the Crown Courts - management hearings. Such a hearing is adversarial - the parties have the opportunity to present arguments (and evidence) in favour of the motion and to confront the arguments of the opposite party. In the process of assessment the judge may conduct an inquiry as to the nature and method of acquiring the evidence. Thus, this procedure is often treated as a "trial within a trial".

In this model the admissibility of evidence is decided by a professional judge in the absence of the jury (which has not normally been appointed yet). However, in the case of a bench trial (and before the magistrates' courts) it is the professional judge who decides on the admissibility of the evidence - the court has discretion to exclude evidence if it would bear unfairly on the proceedings ${ }^{53}$. This is not a rule that the admissibility questions are decided by another judge as recognises the case. Usually magistrates are informed about the nature of the evidence before ruling as to whether it is admissible or not. "If they decide that it

52 LAFAVE, Wayne, ISRAEL, Jerold, KING, Nancy, KERR, Orin. Criminal Procedure. St. Paul: West Academic Publishing, 2009, p. 557.

53 WAINE, Lydia, MAY, Radmila, POWLES, Steven. May on criminal evidence. Sweet \& Maxwel 2015, p. 494. 
is inadmissible they must ignore it" ${ }^{\text {"54 }}$. Thus, in this model of evidentiary proceedings the fact-finder is sometimes faced with the need to disregard evidence that $\mathrm{s} /$ he has knowledge of. However, there are many voices pointing to a need to protect the fact-finder from undesired evidence also in this procedure ${ }^{55}$.

It is also possible to question the admissibility of evidence during a trial. If the party demonstrates that it was not possible to question the admissibility of the evidence earlier, it is possible to submit a motion to supress evidence also during trial. Thus, there is a certain type of "correctional procedure", where the party has a second chance for convincing the judge about inadmissibility of evidence, using new evidence and more convincing arguments. The mechanism of elimination is initiated by a party who submits objection as to the admissibility of evidence and supports it by a legal ground for inadmissibility. In England this procedure is known before the Crown Courts as voir dire ${ }^{56}$ (whereas in the United States the same name is used to describe the procedure in which the composition of a jury may be questioned ${ }^{57}$ ). Because of numerous rules of admissibility of evidence and their complicated structure, in many cases the legal status of information must be explained and decided in actual time of trial. Also in this procedure a presiding judge may "filter" the evidence that will be presented to the fact-finder - if it is a jury trial. Consequently, in this model of trial, a certain part of a trial is devoted to deliberation between counsellors and determining the issues of admissibility. In this procedure every party has an opportunity to present its argumentation as to its position. Only after adversary discussion the court takes a decision: either sustains the objection or overrules it. In practice, when an inadmissibility question is raised, the presiding judge will

54 WAINE, Lydia, MAY, Radmila, POWLES, Steven. May on criminal ... op.cit., p. 301.

55 WAINE, Lydia, MAY, Radmila, POWLES, Steven. May on criminal ... op.cit., p. 494.

56 See: s. 76 and 78 PACE 1984 and more: WAINE, Lydia, MAY, Radmila, POWLES, Steven. May on criminal ... op.cit., p. 477-479.

57 LAFAVE, Wayne, ISRAEL, Jerold, KING, Nancy, KERR, Orin. Criminal Procedure ... op.cit., p. 1084. 
hear the parties in a way that is not audible to jurors: either at sidebar or in chambers ${ }^{58}$. The judge will ask the jurors to leave the courtroom only when the deliberations would take more time. If it happens (as it sometimes does) that the jury is present during deliberation over admissibility of evidence - it will be informed by the presiding judge about the obligation to "disregard" such evidence that was considered to be inadmissible (however, in the United States this should not be done as to search and seizure claims ${ }^{59}$ ). The issues of raising objections in trial are crucial to the way of conducting the presentation of evidence in trial: formulating objections in the right moment of trial is an art of searching for a maximum effect on jurors. Obviously it plays a much smaller role in bench trials.

One of the elements of the mechanism of blocking information is the method of its initiation. For the Anglo-Saxon model a characteristic feature is initiation of the control mechanism by a party - and it is a mechanism of controlling the behaviour of the other party: they are "strategic protests of one lawyer against the tactics of another. And since these objections of counsel do not involve criticism of the ultimate fact finder - the judge, or the jury (...) they can be made by attorneys with relative ease”. The judge has no obligation to control the admissibility of evidence and in practice rarely exercises this control. If any of the parties levers the admissibility of evidence, the evidence is effectively introduced in the evidentiary material. Thus, only the reaction of the opposite party and signalisation of one of the grounds of inadmissibility may result in exclusion of the evidence. On the other hand, the continental lawyer submitting objection as to the admissibility of evidence makes a move against the judge and risks "antagonising those who decide on facts"

58 MIRFIELD, Peter. Silence, Confessions and Improperly Obtained Evidence. Oxford: Oxford University Press, 1998, p. 257; LAFAVE, Wayne, ISRAEL, Jerold, KING, Nancy, KERR, Orin. Criminal Procedure ... op.cit., p. 1166.

59 LAFAVE, Wayne, ISRAEL, Jerold, KING, Nancy, KERR, Orin. Criminal Procedure ... op.cit., p. 569-570.

DAMAŠKA, Mirjam. Evidence Law ...op.cit., p. 86. 


\section{The Continental Approach}

The Continental model does not use any special type of procedure during which evaluation of admissibility of evidence could be undertaken. The "procedure" limits itself to a sole "decision" taken by the court. The admissibility of evidence can be decided on two stages: either during pre-trial procedures (in camera hearings, which in most of the states are not adversarial) or in trial. In both cases this is a single decision of a judge that exhausts the whole "procedure". There is usually no discussion on this topic nor is there an interlocutory appeal allowed. Although there is a "simplified version" of the "adversary" formula: when a party makes a motion, the other party is asked if it supports the motion or objects to it. The decision to reject an evidentiary motion takes the form of a "court's decision", whereas allowing for admittance of evidence can be conclusive ${ }^{61}$. Characteristic to this model, the prosecution usually exhausts its evidentiary motions in the frames of the attachment to an indictment where it formulates the evidence that is wishes to present in trial. Also in this case this attachment is considered to constitute an evidentiary motion and the particular evidentiary motions could be rejected. However, in some states this is not the case. As what evidence will be introduced does not depend on the parties, it often happens that evidentiary motions formulated in the indictment are fully realised, compared to not a single one of the motions of the defence. Poland is a sad example of this tendency.

This model of proceeding on evidentiary motions includes one more trait: once evidence is included in the file of preparatory proceeding there is no procedure for demanding the exclusion of such evidence. There is a tendency to consider as evidence the results of the prosecutor's investigations ${ }^{62}$. In consequence, the existence of a case file leads to

61 ŚWIECKI, Dariusz. Przeprowadzanie dowodów na rozprawie głównej. Wybrane zagadnienia. In: Proces karny w dobie przemian. Przebieg postępowania, STEINBORN, Sławomir; WOŹNIEWSKI, Krzysztof (eds.). Gdańsk: Wydawnictwo UG, 2018, p.283.

62 MARAFIOTI, Luca. Italian Criminal Procedure: A System Caught Between Two Traditions. In: Crime, Procedure and Evidence in a Comparative and International Context: Essays in Honour of Prof. Mirjan Damaška. JACKSON, John; LANGER, Maximo (eds.). Hart Publishing, 2008, p. 93. 
serious malfunction of the system of eliminating evidence: even the results of illegal actions of state authorities must remain "stuck" in the file. Some continental states have noticed the dangers of such a solution and introduced "double-dossier" as Italy, or prohibition of inclusion of police-interrogations in the evidentiary material, as Germany. However, in Poland and France what comes into the file, stays in the file, and the presiding judge before trial has the opportunity to get the knowledge of all evidence taken in the preparatory proceeding - even if s/he decides later that there constituted "evidence" in the phase of preparatory proceedings only but not in trial phase.

This lack of special procedure in continental states is considered to constitute a serious flaw in the mechanism of elimination of evidence. Adopting such a special procedure became one of the main characteristic features of the continental model of trial of increased adversariality. In Italy, not only is there a separate file for the trial stage, but also a separate procedure for deciding about admissibility of evidence. According to art. 431 of the Italian c.p.p. a special "pretrial (preliminary) judge” (giudice dell'udienza preliminare) during a pre-trial hearing decides on the transfer of evidence from the prosecutor's file (the investigative dossier) into the trial file ("fascicolo per il dibattimento"). This system, called the "double dossier-system" ("doppio fascicolo"), was created in order to avoid bias to the trial judge's "virgin mind," guaranteeing that the judge would acknowledge only the evidence produced in court and decide only on that basis. Only certain documents can be transferred ${ }^{63}$. Additionally, the parties can also agree on the transfer of other documents - as well as adding certain evidence gathered by the defence. Thus, the conversion from "preparatory proceeding evidence" into "trial evidence" happens according to the list of documents enumerated in the legal act and to the list as agreed by the parties. The presiding, fact-finding judge has

${ }^{63}$ Art. 431(1) points a-h c.p.p. lists these documents: evidence which is objectively impossible to reproduce in court; results of mutual assistance; evidence that may be lost before trial; physical evidence connected with the crime, and evidence gathered using the incidente probatorio, prior convictions of the accused and such documents on which both parties agree. 
no access to other documents ${ }^{64}$. What is more, the second element of this mechanism of elimination of evidence comes into play in the beginning of a trial: before trial both parties must point to the evidence they plan to rely on and make an evidentiary motion. Before opening of the evidentiary proceeding, after the opening statements, the presiding judge decides on their admissibility (art. 495 c.p.p.). If the question of inadmissibility appears during the evidentiary proceeding, then the judge decides on this stage. The judge is both obliged to decide on the admissibility of every piece of evidence on the motion of the party and ex officio ${ }^{65}$. This admissibility question is rather to settle what information the judge is prepared to hear in the trial, but it does not settle whether it may be finally judged "usable" in the evaluation of evidence ${ }^{66}$. Also in the case of this hybrid model the same person decides on the facts of the case and on the admissibility of evidence ${ }^{67}$.

\section{Consequences of APPLYING A MECHANISM OF ELIMINATION OF EVIDENCE}

Every adopted mechanism of elimination of evidence has elimination of undesired evidence as its goal. However, depending on the type of evidence and the type of its defectiveness, elimination may or may not take place. There are two possibilities: either an automatic elimination on the basis of the legal act or "balancing" of interest in every case on a casuistic basis, taking into consideration the scale of violation of law, its relevance for the judgment and the fair trial principle ${ }^{68}$. Interestingly, the

64 See: MARAFIOTI, Luca. Italian Criminal Procedure ... op.cit., p. 93; ILLUMINATI Giulio. The Frustrated Turn to Adversarial Procedure in Italy (Italian Criminal Procedure Code of 1988). Washington University Global Studies Law Review 2005, p. 6; RYAN, Andrea. Towards a System of European Criminal Justice. The problem of admissibility of evidence, London/New York: Routledge, 2014, p. 227.

65 ILLUMINATI, Giulio. Italy: Statutory Nullities ... op.cit., p. 242-243.

66 See the interviews conducted by A. Ryan with the Italian prosecutors: RYAN, Andrea. Towards a System ... op.cit., p. 218.

67 RYAN, Andrea. Towards a System .. op.cit., p. 218.

68 A good example of this attitude in the Polish law has been given by: D. Solodov, I. Solodov, Legal safeguards against involuntary criminal confessions in 
last element of the mechanism of elimination of undesired evidence has the least differences. In both Anglo-Saxon and continental states there is no automatic exclusionary rule for improperly obtained evidence. The main difference still remains that in one case there are statutory foundations for a judge to decide about the illegality or unreliability and incredibility of evidence, whereas in the continental states (with the exception of Italy) there is no such clear statutory basis.

\section{The Continental Approach}

In the continental model there is no coherent theory as to the consequences of illegal gathering or presentation of evidence. There is no mention of these consequences in the codes of criminal procedure ${ }^{69}$. In the Anglo-Saxon perspective it is often concluded that many European states do not have exclusionary rules that would supress evidence improperly seized by the police ${ }^{70}$. This conclusion is not justified. Firstly, from the reasons mentioned above - that is, the formal character of all the actions taken by procedural authorities in the preparatory proceedings. Secondly, although there is no legal provision forbidding the use of illegal evidence, in most of the continental states the most common (but not the sole) reaction is shifting the final solution to the level of judicial decisions. Thirdly, in some cases the legal act itself mentions the consequences of violation of specific rules of gathering of evidence as it is in the cases of exclusionary rules.

Automatic elimination applies in two cases: firstly, when it comes to the rules of exclusion, and secondly, in the case of "invalidity" of procedural actions (used in order to eliminate evidence that was acquired due to violations of law). As to the remaining deficiencies, the prevailing belief is that the lack of a procedural sanction expressed by the legislator

Poland and Russia, „Rev. Bras. de Direito Processual Penal”, 2020, v. 6(3), p. 1674. About continental procedural solutions also see: K. Kremens, The authority to order search in a comparative perspective: a call for judicial oversight, „Rev. Bras. de Direito Processual Penal”, 2020, v. 6(3), p. 1599-1603.

70 PIZZI, William. Trials Without Truth ... op.cit., s. 43. 
does not mean that such a sanction cannot be applied. The admissibility of deficiently gathered or presented evidence can be freely assessed by a judge, who takes into account the principles arising from the Constitution, the ECHR and generally recognized values. This concept assumes that not every violation of the law in the process of gathering evidence should lead to inadmissibility of evidence, because the type of violation and its impact on the entire procedure should be considered: "the possible elimination of evidence obtained illegally should take place depending on the circumstances of a given case and taking into account many factors, such as the weight of the private interest, the weight of the public interest or the direction of evidence" 71 . This conclusion must, however, be seen from the perspective of the importance of the principle of substantial truth - which plays the central role in a continental trial. Thus, when weighting interest, the continental courts must always look for a proper balance between the protected interests and the obligation of a continental judge to search for the truth ${ }^{72}$. Also, the practical perspective allows for agreement with the statements, that "The disparity between the attention

${ }^{71}$ Such a asumption has been expressed in the Polish literature: WILIŃSKI, Paweł. Pojęcie rzetelnego procesu karnego. In: Rzetelny proces karny w orzecznictwie sądów polskich i międzynarodowych. WILIŃSKI, Paweł (ed.). Warszawa: Scholar, 2011, p. 26; SKORUPKA, Jerzy., Eliminowanie z procesu, p. 2747-2748; JASIŃSKI, Wojciech. Nielegalnie ... op.cit., p. 89; in the German literature: EISENBERG, Ulrich. Beweisrecht der StPO. Spezialkommentar. 10. Auflage. C. H. Beck 2017, p. 141, p. 154-158; GLESS, Sabine. Germany ... op.cit., p. 114; ROGALL, Klaus. Grundsatzfragen der Beweisverbote, p. 145; and in the French literature: DARSONVILLE, Audrey. Les limites au principe de la liberté de la preuve pour les parties, Dalloz. Actualité, https://www.dalloz-actualite.fr/breve/limites-au-principe-de-liberte-de-preuve-pour-parties\#.X2SD7IswhPY (access 18.09.2020); GARÉ, Thierry. L'admission de la preuve illégale: la Chambre criminelle persiste et signe, Recueil Dalloz 2000, p. 391; MOLINA, Emmanuel. Réflexion critique sur l'évolution paradoxale de la liberté de la preuve des infractions en droit français contemporain., Revue internationale de droit comparé, n. 54(1), "2002, p. 263; MERLE, Roger, VITU André. Traité de droit criminel. 2. Procédure pénale. Paris: Cujas, 1989, p. 162-163; PRADEL, Jean. Procédure pénale, Paris: Cujas, 2014, p. 354-357.

72 GLESS, Sabine. Germany ... op.cit., p. 139; WEIGEND, Thomas, The Potential to Secure a Fair Trial Through Evidence Exclusion: A German Perspective. In: Do Exclusionary Rules Ensure a Fair Trial?: A Comparative Perspective on Evidentiary Rules, GLESS, Sabine; RICHTER, Thomas (eds.). Basel: Springer, 2019, p. 73. 
paid in the literature to the various theories behind exclusionary rules and the few actual cases of evidentiary exclusion is striking" ${ }^{\prime 3}$.

In practice, this means that the mechanism of "weighing" legal interests and, as a result, eliminating defective or incorrectly obtained evidence, has been left to the discretion of the courts. Its application and scope most often depend on the stage of the infringement or detection of illegality, as well as the nature and consequences of the violation of law. Especially in Germany the need to find a pattern and model for weighting of various interests in the process of assessing the admissibility of evidence has resulted in the creation of plentiful theories which can guide the judge: a theory based on the type of the protected interests (Rechtkreistheorie), a theory based on the possible violation of the state of law principle (Rechtsstaatsprinzip); a theory of weighting of legal interests (Abwägungstheorie), and the aim of protection expressed in the given provision (Schutzzwecktheorie) or the type of violation of the privacy sphere (schlichte Privatsphäre) ${ }^{74}$.

Only in Italy is there a statutory provision that specifies the prohibition of using illegally obtained evidence (art. 191 c.p.p.). On the other hand it is worth mentioning that the previously discussed mechanism of nullities used in France and Italy is not subject to weighting - in case of fulfilling the statutory premises of nullity of an evidentiary action the results of this action cease to exist in a procedural sense.

In the process of assessment of admissibility of evidence, art. 6 ECHR also plays a distinct role - the Strasbourg Court has developed a notion of a fair trial that has become a key element in the analysis of the admissibility of evidence in criminal procedures by all the State Parties. Article 6 of the Convention refers to the description of the entire model of the criminal trial, to the entire legal situation of the accused, and thus

73 GLESS, Sabine, MACULA, Laura. Exclusionary Rules-Is It Timefor Change? In: Do Exclusionary Rules Ensure a Fair Trial?: A Comparative Perspective on Evidentiary Rules, GLESS, Sabine; RICHTER, Thomas (eds.). Basel: Springer 2019, p. 352.

74 ROGALL, Klaus. Grundsatzfragen der Beweisverbote ... op.cit., p. 145 ; EISENBERG, Ulrich. Beweisrecht, p. 155; SCHRÖDER, Svenja. Beweisverwertungsverbote und die Hypothese rechtmässiger Beweiserlangung im Strafprozess, Berlin: Duncker \& Humblot, 1992, p. 24 and 66. 
to the type and quality of evidence leading to the conclusion of guilt, i.e. the type and method of gathering evidence ${ }^{75}$. The notion of a fair trial - so far characteristic of Anglo-Saxon states - has also penetrated into continental European systems of criminal proceedings and began to give the law of evidence a new quality. The guarantees resulting from this notion become apparent in the case-law of national courts, which are now required to assess the standard of evidence in the light of this.

This multi-level solution allows for differentiating the consequences of violations, depending on the gravity of the violation and the relevance of the violation of the human rights and constitutional principles, such the rule of $\mathrm{law}^{76}$. It is flexible and optimizes the functioning of the rules of elimination. However, at the same time, it makes the results of "weighting" of admissibility of evidence quite unpredictable.

\section{The Anglo-Saxon Approach}

In the common law states there is no automatic exclusionary rule for improperly obtained evidence: there is not necessarily a connection between a violation of law and the elimination of evidence. The courts have accepted that improperly obtained evidence can be excluded in the exercise of discretion if its use would render the trial unfair ${ }^{77}$. Interestingly,

75 See e.g. a more detailed analysis: BACHMAIER, Lorena. Rights and Methods to Challenge Evidence and Witnesses in Civil Law Jurisdictions. In: Oxford Handbook of Criminal Process. BROWN, Darryl et al. (eds.)., Oxford: Oxford University Press, 2019, p. 844-849; HO, Hock Lai. The Fair Trial Rationale for Excluding Wrongfully Obtained Evidence. In: Do Exclusionary Rules Ensure a Fair Trial?: A Comparative Perspective on Evidentiary Rules, GLESS, Sabine; RICHTER, Thomas (eds.). Basel: Springer 2019, p. 284; SOLODOV, Denis; SOLODOV, Ilia. Legal safeguards against involuntary criminal confessions in Poland and Russia, Rev. Bras. de Direito Processual Penal, 2020, v. 6(3), p. 1670.

76 See: BACHMAIER, Lorena. Rights and Methods ... op.cit., p. 853; WILIŃSKI, Paweł. Konstytucyjny standard legalności ... op.cit., p. 319; ROGALL, Klaus. Grundsatzfragen der Beweisverbote ... op.cit., p. 129; SKORUPKA, Jerzy. Eliminowanie z procesu ... op.cit., p. 2787; WEIGEND, Thomas. Germany ... op.cit., p. 114.

77 CHOO, Andrew, NASH Susan. Improperly Obtained Evidence in the Commonwealth: Lessons for England and Wales? The International Journal of 
despite numerous rules of admissibility of evidence existing in the AngloSaxon states, the same mechanism of judiciary discretion is applied. In both England and the United States, it cannot be claimed that the consequences of applying rules of admissibility are strictly prescribed: only the effect of some rules is automatic, once the conditions for their application have been found to exist. Other rules of admissibility lead to a conclusion that the trial judge enjoys a wide discretion whether to admit evidence ${ }^{78}$. The view that is presented in the literature points to the fact that there is a different degree of judicial discretion in relation to various rules of admissibility of evidence. Different rules of admissibility require more or less judicial discretion, requiring contextual application to the facts of a concrete case ${ }^{79}$. Although there is a theoretical differentiation between legal rules of admissibility and judicial discretion - the first ones cannot exist without the second one.

In the English literature it is considered that both the exclusionary and the admissibility rules create grounds for a motion to exclude evidence, however, the final decision is left to the decision of a judge. This decision requires judge a careful balancing of interests and procedural rights: the judge should eliminate a piece of evidence if the harm resulting from such evidence would be bigger than a potential advantage ${ }^{80}$. The Court of Appeal has repeatedly refused to accept that the use of improperly obtained but reliable evidence has adversely affected the fairness of the trial - thus making credibility of evidence, not the method of acquiring

Evidence \& Proof, n. 11, 2007, p. 78.

78

79

80 Review, n. 3, 1977, p. 723; CHOO, Andrew; NASH Susan. What's the Matter with S. 78?, Criminal Law Review, n. 12, 1999, p. 929; DENNIS, Ian, H. Reconstructing the Law of Criminal Evidence. Current Legal Problems n. 42, 1989, p. 21; GREVLING, Katharine. Fairness and the Exclusion of Evidence under s. 78(1) of the Police and Criminal Evidence Act. Law Quarterly Review, n. 113, 1997, p. 667; ORMEROD, David, BIRCH Diane. The evolution of the discretionary exclusion of evidence. Criminal Law Review, n. 9, 2004, p. 767 HO, Hock Lai. The Fair Trial Rationale ... op.cit., p. 294. 
it, the main test for admissibility of evidence ${ }^{81}$. This regime - allowing for the necessary flexibility - makes the judge responsible for "the success of this admissibility regime" ${ }^{82}$. It is the trial judge who is responsible for supplying the most credible and probative information to the jury. Finding the proper balance must take into consideration not only the prerequisites described in the legal act and evidentiary principles of general application but also the European fair trial standards ${ }^{83}$. Also in this case an equal basis for exclusion of evidence constitutes the Human Rights Act 1998, incorporating inter alia art. 6 ECHR. The English law can be characterized by the general absence of fixed rules of automatic inadmissibility and other "bright-line" rules and "rather, a case-by-case approach is favoured" $"$.

In the United States the exclusionary rules are understood as results of violations of the Amendments to the Constitution. At the same time the Constitution is silent as to the results of these violations. The consequences are established in the Supreme Court's jurisprudence, which formerly decided upon an automatic elimination of evidence acquired in a violation of constitutional rights and freedoms. The landmark case was Mapp v. Ohio ${ }^{85}$, where the Court decided that the exclusionary rule applies in state courts - in this regard, that it obliges the exclusion of evidence obtained in violation of the Constitution (typically the Fourth, Fifth or Sixth Amendments). The automatic effect of this rule is however restricted by the exceptions to this rule: the "good faith exception" and the "impeachment exception", as well the exceptions to the "fruits of the poisonous tree doctrine". In consequence, the U.S. exclusionary rules

81 CHOO, Andrew, NASH Susan. Improperly Obtained ... op.cit., p. 79. JACKSON, John, D, SUMMERS, Sarah, J. The Internationalisation of Criminal Evidence. Cambridge: Cambridge University Press, 2012, p. 38; CHOO, Andrew. England and Wales: Fair Trial Analysis and the Presumed Admissibility of Physical Evidence. In: THAMAN, Stephen (ed.). Exclusionary Rules in Comparative Law, Dordrecht - Heidelberg - New York - London: Springer, 2013, p. 352. 
were historically considered to be more categorical than the English and continental rules and usually were not subject to balancing ${ }^{86}$.

Currently, however, the Supreme Court's approach to the exclusion of illegally obtained evidence is characterized by a parsimonious conception of the rights guaranteed by the constitution based on (or justified by) a textualist theory of constitutional interpretation. E.g. the Court has unequivocally rejected the proposition that exclusion of illegally seized evidence is required by the Fourth Amendment, and regards the exclusionary rule as a judicially created deterrent remedy designed to protect the right against unreasonable search and seizures ${ }^{87}$. In the process of refusing to consider evidence as inadmissible, described as "deconstitutionalization of the exclusionary rule" ${ }^{88}$, the perception of the nature of exclusionary rules has changed. They have moved from being an institution belonging to the area of "individual's rights" into the area of "sanction for violation of the law", a "remedy", whose main aim is to discipline the procedural authorities - although there is no final agreement on this in either jurisprudence or doctrine ${ }^{89}$. The Supreme Court recently stated that the exclusionary rule is applicable only "where its deterrence benefits outweighs its substantial social costs" (so called "cost-benefit balancing" $)^{90}$. In consequence, if the deterrence potential of the rule is

86 The perspective adopted in some of the U.S. literature, e.g. WORRALL, John L. Criminal Procedure. From First Contact to Appeal. New York: Pearson Education 2007, p. 56.

CAMMACK, Mark E. The United States: The Rise and Fall of the Constitutional Exclusionary Rule. In: Exclusionary Rules in Comparative Law. THAMAN, Stephen. (ed.)., Dordrecht - Heidelberg - New York - London: Springer, 2013, p. 4 and 10; LAFAVE, Wayne, ISRAEL, Jerold, KING, Nancy, KERR, Orin. Criminal Procedure ... op.cit., p. 133-136.

CAMMACK, Mark E. The United States ... op.cit., p. 31. See also the jurisprudence: Herring v. United States, 555 U.S. 135 (2009), 129 S.CT. 695, 172 L.Ed.2d 496 (2009); Kansas v. Ventris, 129 S.Ct. 1841, 1846 (2009).

See e.g. Dickerson v. United States 530 U.S. 428 (2000).

So called „cost-beneft” balancing, used e.g. in Hudson v. Michigen, 547 U.S. 586, 126 S.Ct. 2159, 165 L.Ed.2d 56 (2006). See e.g.: CAMMACK, Mark E. The United States ... op.cit., p. 5; LAFAVE, Wayne, ISRAEL, Jerold, KING, Nancy, KERR, Orin. Criminal Procedure ... op.cit., p. 139; PATTENDEN, Rosemary. Pre-verdict Judicial Fact-finding in Criminal Trials with Juries, Oxford Journal of Legal Studies, n. 29(1), 2009, p. 17; HO, Hock Lai. Exclusion of Wrongfully, p. 835. 
too negligible or if it is outweighed by the costs of the exclusionary rule, then exclusion should not happen ${ }^{91}$. The Court's attitude is summed up by saying that exclusion "has always been our last resort, not our first impulse" ${ }^{2}$. However, the balancing does not depend on the circumstances of the adjudicated case, but rather on a category of evidence that serves a certain purpose $\mathrm{e}^{93}$.

If exclusionary rules are provided for in state law, the rules are different: in some cases the provision actually says that the sanction is exclusion of evidence. In other cases courts may utilize the exclusionary rule when the provision in question confers a substantial right, especially if it is one that can be said to relate rather closely to constitutional protection ${ }^{94}$. In consequence, also in this model of elimination of evidence, there are no automatic consequences of violation of the law in the process of gathering evidence and the final decision is handed to the judge. However, in this case the balancing happens in decidedly more restricted frames.

\section{Conclusions}

The analysis conducted in this text led to several conclusions. Firstly, there are two stages where the admissibility rules operate in two different models of criminal trial. In the continental model, the main body of rules of evidence must be applied during preparatory proceedings, whereas in the common law states the rules of evidence are designed to be used at trial. As a result, the continental states do not have statutory

91 See: Herring v. United States 555 U.S. 135 (2009).

92 In Herring v. United States 555 U.S. 135 (2009) a case cited by: CAMMACK, Mark E. The United States ... op.cit., s. 32.

93 See: TURNER, Jenia I. Regulating Interrogations and Excluding Confessions in the United States: Balancing Individual Rightsand the Search for the Truth. In: Do Exclusionary Rules Ensure a Fair Trial?: A Comparative Perspective on Evidentiary Rules, GLESS, Sabine; RICHTER Thomas (eds.). Basel: Springer, 2019, p. 104.

94 E.g. U.S. v. Caceres, 440 U.S. 741, 99 S. Ct. 1465, 49 L.Ed.2d 733 (1979) and Virginia v. Moore 553 U.S. 128 S.Ct. 1598, 170 L.Ed.2d 559 (2008) cited by: LAFAVE, Wayne, ISRAEL, Jerold, KING, Nancy, KERR, Orin. Criminal Procedure ... op.cit.,p. 136. 
provisions that would forbid the use of illegally obtained evidence, whereas the Anglo-Saxon model provides for multiple rules of admissibility and presentation of evidence at trial. Secondly, the lack of detailed statutory rules of admissibility and presentation of evidence at trial is bound to the deciding role of the continental judge during evidentiary proceedings. In the common law model the parties decide about the scope and way of presentation of evidence, within the rules provided by the law. The judge plays a central role as to both deciding about admissibility and the rules of presentation of evidence. Thirdly, in continental trials, evidence collected in the case file plays a predominant role in the mechanism of elimination of evidence - once evidence is included in the file it must stay there, even if disqualified in the process of fact-finding - declared by the judge "inadmissible". It also creates the situation that the adjudicating judge is familiar with the evidence that can be later declared "inadmissible". At the same time in the common law model, the judge has no prior knowledge of the evidence that will be presented at trial. The fifth difference between the analysed models relates to the presence of an effective and equal to the parties procedure of deciding about admissibility of evidence in the Anglo-Saxon model of evidentiary law. This procedure allows the parties to control the admissibility of evidence and permanently eliminate inadmissible items from the trial. However, there is no similar procedure in the continental model.

Although the exclusion of undesired information is administered differently in the two analysed models of criminal trial, the result of these mechanisms may be similar. In every analysed model of elimination of evidence, notwithstanding its affiliation to the model of trial whether it would be continental or Anglo-Saxon, the final arbiter of admissibility of evidence is a judge. $S /$ he takes the final decision as to the evidence ${ }^{95}$. In consequence, both legal models can be perceived as chaotic and casuistic, as there is no certainty for the parties as to the final decision of a judge "as predictability in the application of an exclusionary rule increases with its determinacy" ${ }^{\prime 6}$. This model is often perceived as dependant on the

95 GALLIGAN, Denis, James. Discretionary Powers, Oxford: Clarendon Press, 1986, p. 6, 8 and 22.

96 HO, Hock Lai. Exclusion of Wrongfully ... op.cit., p. 835. 
personal skills and convictions of the actors of the trial: both the judge and the representatives of the parties. On the other hand, this model is also flexible and allows for weighting legally protected interests in every case. It does not signify that the judge has total liberty as to the result of such a decision. A judge must take into consideration not only "external" premises - such as the purpose of truth-finding and of fairness and justice, an assessment of the purpose of a given action and its circumstances, the rightness of its performance, in view of the existence of general clauses in a given case $\mathrm{e}^{97}$ - but also intrinsic arguments, rooted in the judge's conscience. Such a task requires from a judge to have certain skills in legal science and a stable sense of justice. Moreover, the judge's decision may be subject to review by the court of appeal.

The analysis presented above also leads to the conclusion that the Anglo-Saxon model of elimination of undesired evidence is very complex, but coherent and carefully designed. It allows for equal participation by both parties and for effective procedures of challenging the admissibility of evidence. On the other hand, the mechanism for blocking information from becoming evidence in the continental model does not function in a predictable, way as there are several deficiencies identified in this model. In the continental states it cannot be said that there is a comprehensive "mechanism" for blocking information from becoming evidence in a criminal trial - it is rather a partial mechanism, quite unpredictable. It can be thus seen that in the continental model there are evident defects in the mechanism of elimination of undesired evidence.

Firstly, there is no statutory basis for excluding illegal or illegally acquired evidence (except for the hybrid model of Italy) - and without such a clear basis for excluding evidence, motions of the parties (usually defence) to exclude illegal evidence become often disregarded by the court. Potentially the court may base decisions on only art. 6 ECHR or the national Constitutions ${ }^{98}$. Secondly, there is no separate procedure that allows for conducting an adversarial, a priori elimination of undesired evidence. The assumption that there is a need to eliminate undesirable evidence should presuppose the existence of an effective procedure allowing a party to

97 PATTENDEN, Rosemary. Pre-verdict ... op.cit., p. 4.

98

GLESS, Sabine; MACULA Laura. Exclusionary Rules ... op.cit., p. 361. 
apply for the elimination of such evidence. Even if in bench trials it is the professional judge who decides about the admissibility of evidence, holding the role of fact-finder at the same time, the procedure for deciding on the admissibility of evidence in the Anglo-Saxon model is equal and the same for both parties. Meanwhile, in the continental model, the judge examines the evidence in the case file; as a result, as a rule, $\mathrm{s} /$ he becomes familiar with all prosecution evidence collected during the preparatory proceedings. This conclusion leads to the third serious flaw of this model, that is the previous knowledge of a judge about the evidence gathered in the preparatory proceedings, which is not yet evidence from the point of view of the trial stage. So even if a piece of information does not ultimately become evidence in court proceedings, "the damage has already been done": the judge already has knowledge of evidence that can be potentially illegal, unreliable and irrelevant to the case ${ }^{99}$. Fourthly, the unitary structure of the continental court (also in the jury trials in France and Italy where both the professional judges and the jury member adjudicate together) also makes it more difficult to "hide" the illegal evidence from the eyes of the fact-finder ${ }^{100}$. Yet, it should be clear, that the aim of the elimination mechanism is not including undesired evidence in the evidentiary basis for fact-finding. Moreover, there is no procedure in which the defense could request that the evidence contained in the case-file be declared inadmissible. The defense can make a free (not regulated in the code of criminal procedure) motion during trial - however, there is no obligation on the part of the court to react to this motion.

These "deficiencies" of the continental model lead to a conclusion that this model of elimination of evidence is incoherent: the obligation to eliminate evidence from the fact-finding process should be bound with the court's legal prohibition to become acquainted with such evidence. The blockade should lead to the fact that such evidence "disappears” in the procedural sense - it is also eliminated from the case files. The "evidence" cannot be considered to be everything that is in the case

99 Even thought the law forces the judge to „forget about" such evidence: - see: WEIGEND, Thomas. The Potential to Secure ... op.cit., p. 75.

${ }^{100}$ It was also observed by: BACHMAIER, Lorena. Rights and Methods ... op.cit., p. 854 . 
file. Such documents cannot constitute the basis for making evidentiary findings, if there is no signal or decision proving that the court was acquainted with such documents before or during the trial, in order to rule on their admissibility.

These two problems could be solved by introducing a construction characteristic for the mixed procedure model of increased adversariality as functions in Italy. A pre-trial hearing presided over by a pre-trial judge would allow for the selection of evidence gathered in preparatory proceedings (by both parties) so that undesired evidence would not reach the eyes of the fact-finder. Such a selection process should therefore take place mostly before trial, and be led by a judge who will not preside over the case during trial. This additional stage of procedure - taking place during a type of pre-trial hearing, would allow the parties to meet and debate over admissibility of evidence - and thus to control their admissibility. Also, importantly for the continental models, such a hearing would become an "indirect form of judicial control over the actions taken in the preparatory proceedings" 101 - especially in the states where there is no investigative judge. Moreover, the result of determining a piece of evidence as inadmissible should be the practical elimination of such documents from the case file. On both stages of trial the rules of admissibility should be effectively used in a way that is equal for both parties. There is also a need for introducing an obligatory reaction on the part of the court to a motion of the parties as to inadmissibility of evidence. Granting the parties such a right would be an expression of respecting the procedural principles included in the code in a criminal procedure, such as the right to defence and to a fair trial, the principle of legality of the actions of procedural organs, the principle of procedural loyalty, all of which also result from broader constitutional, conventional and international law values ${ }^{102}$.

It should be stressed that a criminal trial can be considered to be adversarial only if the rules of admissibility of evidence operate on

${ }^{101}$ This need is stressed in the Polish literature, see: ZAGRODNIK, Jarosław. Model interakcji postępowania przygotowawczego oraz postępowania głównego w procesie karnym. Warszawa: Wolter Kluwer 2013, p. 193.

${ }^{102}$ SKORUPKA, Jerzy. Eliminowanie z procesu ... op.cit., p. 2805. 
equal terms for both parties, and when the issues of admissibility are adjudicated in a clear and equal procedure. There is a connection between the operating mechanism of elimination of undesired evidence and the degree of implementation of fair trial principles. In the continental states the obligation of the judge to search for the true account of event leads to a "free proof" principle and total discretion for the judge to decide on the admissibility of evidence. In the Anglo-Saxon states the central position of the adversariality principle leads to the dominant position of the parties in the mechanism of elimination of evidence. The parties both decide on what evidence will be presented in trial and whether to object to the admissibility of the evidence introduced by the other party. If the continental models move to be "adversarial" - even if not in a clear, full meaning of this notion as used by the Anglo-Saxon states, but in the meaning of being "contradictoire" 103 , that is in compliance with the requirements of art. $6 \mathrm{ECHR}$ - they could improve the procedure of ruling on admissibility of evidence. Certainly the current situation, where the judge is acquainted before trial with the evidence presented by the prosecution and there is a "free flow" of "preparatory proceedings evidence" into the group of "trial evidence" is unacceptable and cannot be justified on the basis of a claim that the prosecutor is a "guardian of law" in the continental states, as this claim does not withstand the test of practice.

\section{References}

AMELUNG, Knut. Zasady rządzące zakazami wykorzystania dowodów. In: Współczesne problemy procesu karnego i wymiaru sprawiedliwości. Księga ku czci Profesora Kazimierza Marszała. HOFMAŃSKI, Piotr; ZGRYZEK, Kazimierz (eds.). Katowice: Wydawnictwo Uniwersytetu Śląskiego, 2003.

ASHWORTH, Andrew J. Excluding Evidence as Protecting Rights. Criminal Law Review, n. 3, 1977.

${ }^{103}$ See: RYAN, Andrea. Towards a System ... op.cit., p. 245 who claims that the notions of „adversarial” and „contradictoire” are not a translation of the same concept; the procedural format in France and Italy cannot be described as adversarial - however, as it has all the features required by art. 6(3)(d) ECHR, it cannot be described as ,inquisitorial” either. 
BACHMAIER, Lorena. Rights and Methods to Challenge Evidence and Witnesses in Civil Law Jurisdictions. In: Oxford Handbook of Criminal Process. BROWN, Darryl et al. (eds.). Oxford: Oxford University Press, 2019. http://doi.org/10.1093/ oxfordhb/9780190659837.013.43

BENEDICT, Jerome. Le sort des preuves illégales dans le procés pénal. Lausanne: Editions Pro Schola, 1994.

BILLIS, Emmanouil. Die Rolle des Richters im adversatorischen und im inquisitorischen Beweisverfahren, Berlin: Duncker \& Humblot, 2015.

CAMMACK, Mark E. The United States: The Rise and Fall of the Constitutional Exclusionary Rule. In: Exclusionary Rules in Comparative Law. THAMAN, Stephen. (ed.). Dordrecht - Heidelberg - New York - London: Springer, 2013.

CHOO, Andrew. England and Wales: Fair Trial Analysis and the Presumed Admissibility of Physical Evidence. In: Exclusionary Rules in Comparative Law. THAMAN, Stephen (ed.). Dordrecht - Heidelberg - New York - London: Springer, 2013.

CHOO, Andrew; NASH Susan. Improperly Obtained Evidence in the Commonwealth: Lessons for England and Wales? The International Journal of Evidence \& Proof, n. 11, 2007.

CHOO, Andrew; NASH Susan. What's the Matter with S. 78? Criminal Law Review, n. 12, 1999.

DAMAŠKA, Mirjam. Evidence Law Adrift, Yale: Yale University Press, 1997.

DAMAŠKA, Mirjam. Evidentiary barriers to conviction and two models of criminal procedure: a comparative study. University of Pennsylvania Law Review, n. 121, 1973

DAMAŠKA, Mirjam. Free Proof and Its Detractors. The American Journal of Comparative Law, n. 3(43), 1995.

DAMAŠKA, Mirjam. On Structures of Authority and Comparative Criminal Procedure. Yale Law Journal, n. 84, 1974-1975.

DAMAŠKA, Mirjam. The Faces of Justice and State Authority. New Haven-London: Yale University Press, 1986.

DARSONVILLE, Audrey. Les limites au principe de la liberté de la preuve pour les parties, Dalloz. Actualité, https://www.dalloz-actualite.fr/breve/limites-auprincipe-de-liberte-de-preuve-pour-parties\#.X2SD7IswhPY (access 18.09.2020);

DENNIS, Ian. H. Reconstructing the Law of Criminal Evidence. Current Legal Problems. n. 42, 1989. 
EISENBERG, Ulrich. Beweisrecht der StPO. Spezialkommentar. 10. Auflage. C. H. Beck 2017.

FULLER, Lon, L. The Adversary System. In: Talks On American Law. BERMAN, Harold (ed.). New York: Vintage Books, 1971.

GALLIGAN, Denis, James. Discretionary Powers, Oxford: Clarendon Press, 1986.

GARÉ, Thierry. L'admission de la preuve illégale: la Chambre criminelle persiste et signe, Recueil Dalloz 2000.

GIUDICELLI-DELAGE, Geneviève. Les transformations de l'administration de la preuve pénale. Perspectives comparées: Allemagne, Belgique, Canada, Espagne, Etats-Unis, France, Italie, Portugal, Royaume-Uni. Archives de politique criminelle, n. 26(1), 2004. https://doi.org/10.3917/apc.026.0139

GLENN, Patrick, H. Legal Traditions of the World. Oxford: Oxford University Press 2014.

GLESS, Sabine. Germany: Balancing Truth Against Protected Constitutional Interests., In: Exclusionary Rules in Comparative Law. THAMAN, Stephen (ed.). Dordrecht - Heidelberg - New York - London: Springer 2013. https://doi. org/10.1007/978-94-007-5348-8_5

GLESS, Sabine. Das Verhältnis von Beweiserhebungs-und Beweisverwertungsverboten und das Prinzip »Iocus regit actum. In: Festschrift für Gerald Grünwald, SAMSON, Erich; DENCKER, Friedrich; FRISCH, Peter; FRISTER, Helmut; REIß, Wolfram (eds.). Baden-Baden: Nomos, 1999.

GLESS, Sabine, MACULA, Laura. Exclusionary Rules-Is It Timefor Change? In: Do Exclusionary Rules Ensure a Fair Trial?: A Comparative Perspective on Evidentiary Rules, GLESS, Sabine; RICHTER, Thomas (eds.). Basel: Springer 2019. https://doi.org/10.1007/978-3-030-12520-2_12

GREVLING, Katharine. Fairness and the Exclusion of Evidence under s. 78(1) of the Police and Criminal Evidence Act. Law Quarterly Review, n. 113, 1997.

GRÜNWALD, Gerald. Das Beweisrecht der Strafprozeßordnung, Baden-Baden: Nomos, 1993.

HANNIBAL, Martin; MOUNTFORD, Lisa. Criminal Litigation 2019-2020 (Legal Practice Course Manuals), Oxford: Oxford University Press, 2019.

HO, Hock Lai. Exclusion of Wrongfully Obtained Evidence: A Comparative Analysis. In: Oxford Handbook of Criminal Process. BROWN, Darryl et al. (eds.)., Oxford: Oxford University Press, 2019. 
HO, Hock Lai. The Fair Trial Rationale for ExcludingWrongfully Obtained Evidence. In: Do Exclusionary Rules Ensure a Fair Trial?: A Comparative Perspective on Evidentiary Rules, GLESS, Sabine; RICHTER, Thomas (eds.). Basel: Springer 2019.

ILLUMINATI, Giulio. Italy: Statutory Nullities and Non-usability., In: Exclusionary Rules in Comparative Law. THAMAN Stephen (ed.). Dordrecht Heidelberg New York London: Springer, 2013.

ILLUMINATI, Giulio. The Frustrated Turn to Adversarial Procedure in Italy (Italian Criminal Procedure Code of 1988). Washington University Global Studies Law Review 2005.

JACKSON, John, D.; SUMMERS Sarah, J. The Internationalisation of Criminal Evidence. Cambridge: Cambridge University Press, 2012.

JASIŃSKI, Wojciech. Nielegalnie uzyskane dowody w procesie karnym. W poszukiwaniu optymalnego rozwiązania. Warszawa: Wolters Kluwer, 2019.

KERN, Eduard; ROXIN, Claus. Strafverfahrensrecht: ein Studienbuch. München: Beck, 1987.

KLEINKNECHT, Theodor. Die Beweisverbote im Strafprozess. Neue Juristische Wochenschrift, n. 19, 1966.

KREMENS, Karolina, The authority to order search in a comparative perspective: a call for judicial oversight, Rev. Bras. de Direito Processual Penal, n. 6(3), 2020. https://doi.org/10.22197/rbdpp.v6i3.412

KWIATKOWSKI, Zbigniew. Model zakazów dowodowych de lege lata w polskim procesie karnym. In: Nowe spojrzenie na model zakazów dowodowych w procesie karnym. SKORUPKA, Jerzy (ed.). Warszawa 2014.

LAFAVE, Wayne, ISRAEL, Jerold, KING, Nancy, KERR, Orin. Criminal Procedure. St. Paul: West Academic Publishing, 2009.

LANGER, Maximo. From Legal Transplants to Legal Translations: The Globalization of Plea Bargaining and the Americanization Thesis in Criminal Procedure', Harvard International Law Journal. n. 1(45), 2004.

MARAFIOTI, Luca. Italian Criminal Procedure: A System Caught Between Two Traditions. In: Crime, Procedure and Evidence in a Comparative and International Context: Essays in Honour of Prof. Mirjan Damaška. JACKSON, John; LANGER, Maximo (eds.). Hart Publishing 2008.

MERLE, Roger; VITU André. Traité de droit criminel. 2. Procédure pénale. Paris: Cujas, 1989. 
MIRFIELD, Peter. Silence, Confessions and Improperly Obtained Evidence. Oxford: Oxford University Press, 1998.

MOLINA, Emmanuel. Réflexion critique sur l'évolution paradoxale de la liberté de la preuve des infractions en droit français contemporain., Revue internationale de droit comparé, n. 54(1), 2002.

NIJBOER, Johannes, F. Methods of Investigations and Exclusion of Evidence - a Comparative and Interdisciplinary Perspective. In: Beweisverbote in Ländern der EU und vergleichbaren Rechtsordnungen. HÖPFEL, Frank, HUBER, Barbara (eds.). Freiburg in Breisgau: Max-Planck-Institut, 1999.

ORMEROD, David; BIRCH Diane. The evolution of the discretionary exclusion of evidence. Criminal Law Review, n. 9, 2004.

PATTENDEN, Rosemary. Pre-verdict Judicial Fact-finding in Criminal Trials with Juries, Oxford Journal of Legal Studies, n. 29(1), 2009.

PIZZI, William. Trials Without Truth: Why Our System of Criminal Trials Has Become an Expe,nsive Failure and What We Need to Do to Rebuild. New York: NYU Press, 1998.

PRADEL, Jean. La preuve en procédure pénale comparée. Rapport general, Revue International de Droit Penal 1992.

PRADEL, Jean. Procedural Nullities and Exclusion. In: Exclusionary Rules in Comparative Law. THAMAN Stephen (ed.). Dordrecht - Heidelberg - New York London: Springer, 2013.

PRADEL, Jean. Procédure pénale, Paris: Cujas, 2014.

ROBERTS, Paul; ZUCKERMAN, Adrian. Criminal Evidence. Oxford: Oxford University Press, 2012.

ROBERTS, Paul. Faces of Justice Adrift? Damaška's Comparative Method and the Future of Common Law Evidence. In: Crime, Procedure and Evidence in A Comparative and International Context - Essays in Honour of Professor Mirjan Damaška. JACKSON, John; LANGER, Maximo (eds.). Oxford: Hart Publishing, 2008.

ROGALL, Klaus. Grundsatzfragen der Beweisverbote. In: Beweisverbote in Ländern der EU und vergleichbaren Rechtsordnungen. HÖPFEL Frank; HUBER Barbara (eds.). Freiburg in Breisgau: Max-Planck-Institut, 1999.

ROGALL, Klaus. Beweisverbote im System des deutschen und des amerikanischen Strafverfahrens-rechts. In: Zur Theorie und Systematik des Strafprozessrechts: 
Symposium zu Ehren von Hans-Joachim Rudolphi WOLTER, Jürgen (ed.). Berlin: Luchterhand, 1995.

ROSS, Jacqueline. Do Rules of Evidence Apply (Only) in the Courtroom? Deceptive Interrogation in the United States and Germany. Oxford Journal of Legal Studies, n. 3(28), 2008.

RYAN, Andrea. Towards a System of European Criminal Justice. The problem of admissibility of evidence, London/New York: Routledge, 2014.

SCHRÖDER, Svenja. Beweisverwertungsverbote und die Hypothese rechtmässiger Beweiserlangung im Strafprozess, Berlin: Duncker \& Humblot, 1992.

SKORUPKA, Jerzy., Eliminowanie z procesu karnego dowodów uzyskanych w sposób sprzeczny z prawem. In: Dowody. Vol. VIII(2), System Prawa Karnego Procesowego SKORUPKA, Jerzy (ed.). Warszawa: Wolters Kluwer 2019.

SOLODOV, Denis; SOLODOV, Ilia. Legal safeguards against involuntary criminal confessions in Poland and Russia, Rev. Bras. de Direito Processual Penal, 2020, v. 6(3). https://doi.org/10.22197/rbdpp.v6i3.368

STEINBORN, Sławomir. Aksjologiczne uwarunkowania ograniczeń w dochodzeniu do prawdy materialnej w procesie karnym. In: Pojęcie, miejsce i znaczenie prawdy materialnej w polskim procesie karnym: materiały Wrocławskiego Seminarium karnoprocesowego. SKORUPKA, Jerzy; KREMENS, Karolina (eds.). Wrocław 2013.

ŚWIECKI, Dariusz. Przeprowadzanie dowodów na rozprawie głównej. Wybrane zagadnienia. In: Proces karny w dobie przemian. Przebieg postępowania, STEINBORN, Sławomir, WOŹNIEWSKI, Krzysztof (eds.). Gdańsk: Wydawnictwo UG, 2018.

THAMAN, Stephen. Balancing Truth Against Human Rights: A Theory of Modern Exclusionary Rules. In: Exclusionary Rules in Comparative Law THAMAN Stephen (ed.). Dordrecht - Heidelberg - New York - London: Springer, 2013.

THIBAUT, John; WALKER, Lauren; LIND, E. Allan. Adversary presentation and bias in legal decisionmaking. Harvard Law Review. n. 86, 1972-1973. https://doi. org/10.2307/1339895

TRÜG, Gerson. Lösungskonvergenzen trotz Systemdivergenzen im deutschen und US-amerikanischen Strafverfahren. Tübingen: Mohr Siebeck, 2003.

TURNER, Jenia I. Regulating Interrogations and Excluding Confessions in the United States: Balancing Individual Rightsand the Search for the Truth. In: Do Exclusionary Rules Ensure a Fair Trial?: A Comparative Perspective on Evidentiary 
Rules, GLESS, Sabine; RICHTER Thomas (eds.). Basel: Springer, 2019. https:// doi.org/10.1007/978-3-030-12520-2_493

TURNER, Jenia I.; WEIGEND, Thomas, The Purposes and Functions of Exclusionary Rules: A Comparative Overview. In: Do Exclusionary Rules Ensure a Fair Trial?: A Comparative Perspective on Evidentiary Rules, GLESS, Sabine; RICHTER, Thomas (eds.). Basel: Springer, 2019. https://doi.org/10.1007/978-3-030-12520-2_8

TWINNING, William. Theories of Evidence: Bentham and Wigmore. (Jurists: Profiles in Legal Theory). London: Stanford University Press, 1985.

VAN CAENEGEM, William. New trends in illegal evidence in criminal procedure: general report - common law, Paper presented at XIII World Congress of Procedural law, Rio de Janeiro, Brazil. https://research.bond.edu.au/en/publications/ new-trends-in-illegal-evidence-in-criminal-procedure-general-repo (access: 18.11.2020).

WAINE, Lydia; MAY, Radmila; POWLES, Steven. May on criminal evidence. Sweet \& Maxwel 2015.

WALTOŚ, Stanisław. Rola sądu w postępowaniu przygotowawczym. Problemy Praworządności, n. 1, 1971.

WĄSEK-WIADEREK, Małgorzata., Model zakazów dowodowych z perspektywy Konwencji i orzecznictwa ETPCz., In: Nowe spojrzenie na model zakazów dowodowych w procesie karnym. SKORUPKA, Jerzy (ed.). Warszawa 2015.

WEBER, Max. On Law in Economy and Society. Harvard: Harvard University Press, 1954.

WEIGEND, Thomas. Germany. In: Toward a Prosecution for the European Union. Vol I. LIGETI, Katalin (ed.), Oxford: Hart Publishing, 2013.

WEIGEND, Thomas. The Potential to Secure a Fair Trial Through Evidence Exclusion: A German Perspective. In: Do Exclusionary Rules Ensure a Fair Trial?: A Comparative Perspective on Evidentiary Rules, GLESS, Sabine; RICHTER, Thomas (eds.). Basel: Springer, 2019.

WILIŃSKI, Paweł. Konstytucyjny standard legalności dowodu w procesie karnym In: Proces karny w dobie przemian. Zagadnienia ogólne. STEINBORN, Sławomir; WOŹNIEWSKI, Krzysztof (eds.). Gdańsk: Wydawnictwo UG, 2018.

WILIŃSKI, Paweł. Pojęcie rzetelnego procesu karnego. In: Rzetelny proces karny w orzecznictwie sądów polskich i międzynarodowych. WILIŃSKI, Paweł (ed.). Warszawa: Scholar, 2011. 
WORRALL, John L. Criminal Procedure. From First Contact to Appeal. New York: Pearson Education 2007.

ZAGRODNIK, Jarosław. Model interakcji postępowania przygotowawczego oraz postępowania głównego w procesie karnym., Warszawa: Wolters Kluwer 2013.

\section{Additional information and author's declarations (scientific integrity)}

Acknowledgement: The research project was financed from the funds of the National Centre of Science (Narodowe Centrum Nauki) granted on the basis of a contract No. UMO-2016/21/B/ HS5/02061 for a project entitled "Compatibility of procedural institutions - selected problems of internal harmony of a criminal procedure model".

Conflict of interest declaration: the author confirms that there are no conflicts of interest in conducting this research and writing this article.

Declaration of authorship: all and only researchers who comply the authorship requirements of this article are listed as authors; all coauthors are fully responsible for this work in its entirety.

Declaration of originality: the author assures that the text here published has not been previously published in any other resource and that future republication will only take place with the express indication of the reference of this original publication; she also attests that there is no third party plagiarism or self-plagiarism. 


\section{Editorial process information}

(http://www.ibraspp.com.br/revista/index.php/RBDPP/about/editorialPolicies)

- Submission date: 07/12/2020

- Preliminary control and similarity verification: 04/01/2021

- Review 1: 12/01/2021

- Review 2: 18/01/2021

- Review 3: 27/01/2021

- Editorial decision 1: 02/02/2021

- Correction round return: 17/02/2021

- Final editorial decision: 18/02/2021
Editorial team responsible

- Editor-in-chief: 1 (VGV)

- Associated-editor: $1(\mathrm{KK})$

- Reviewers: 3

\section{HOW TO CITE (ABNT BRAZIL):}

KUCZYŃSKA, Hanna. Mechanisms of elimination of undesired evidence from criminal trial: a comparative approach. Revista Brasileira de Direito Processual Penal, Porto Alegre, vol. 7, n. 1, p. 43-92, jan./abr. 2021. https://doi.org/10.22197/rbdpp.v7i1.473

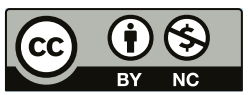

Esta obra está licenciada com uma Licença Creative Commons Atribuição-NãoComercial 4.0 Internacional. 